Prepared in cooperation with the Naval Facilities Engineering Command-Northwest

\title{
Numerical Simulation of Groundwater Flow at Puget Sound Naval Shipyard, Naval Base Kitsap, Bremerton, Washington
}

Open-File Report 2016-1135 



\section{Numerical Simulation of Groundwater Flow at Puget Sound Naval Shipyard, Naval Base Kitsap, Bremerton, Washington}

By Joseph L. Jones, Kenneth H. Johnson, and Lonna M. Frans

Prepared in cooperation with the Naval Facilities Engineering Command-Northwest

Open-File Report 2016-1135

U.S. Department of the Interior

U.S. Geological Survey 


\section{U.S. Department of the Interior \\ SALLY JEWELL, Secretary}

\section{U.S. Geological Survey \\ Suzette M. Kimball, Director}

U.S. Geological Survey, Reston, Virginia: 2016

For more information on the USGS—-the Federal source for science about the Earth,

its natural and living resources, natural hazards, and the environment-visit

http://www.usgs.gov/ or call 1-888-ASK-USGS (1-888-275-8747).

For an overview of USGS information products, including maps, imagery, and publications, visit http://store.usgs.gov.

Any use of trade, firm, or product names is for descriptive purposes only and does not imply endorsement by the U.S. Government.

Although this information product, for the most part, is in the public domain, it also may contain copyrighted materials as noted in the text. Permission to reproduce copyrighted items must be secured from the copyright owner.

Suggested citation:

Jones, J.L., Johnson, K.H., and Frans, L.M., 2016, Numerical simulation of groundwater flow at Puget Sound Naval Shipyard, Naval Base Kitsap, Bremerton, Washington: U.S. Geological Survey Open-File Report 2016-1135, 3』p., http://dx.doi.org/10.3133/ofr20161135.

ISSN 2331-1258 (online) 


\section{Contents}

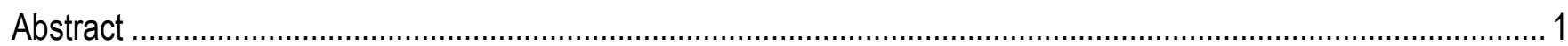

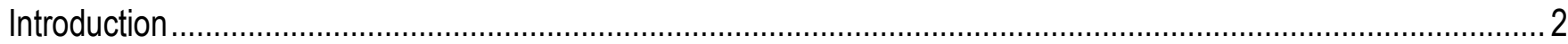

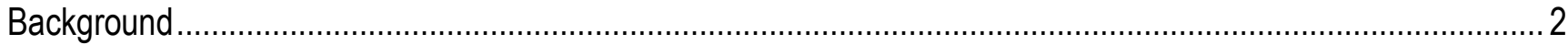

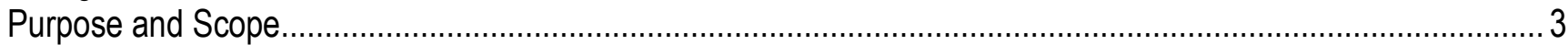

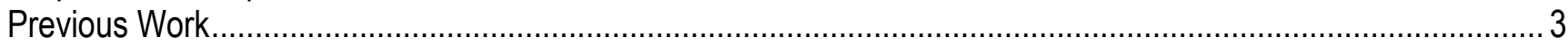

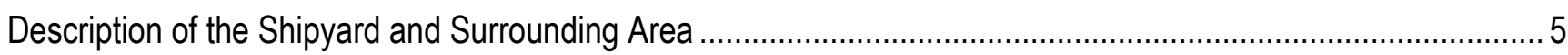

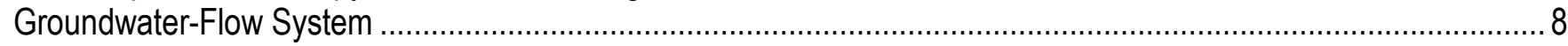

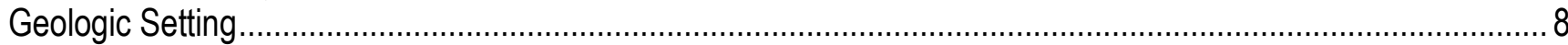

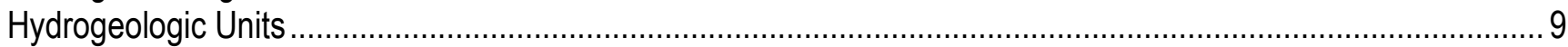

Hydraulic Conductivity ..................................................................................................................... 10

Conceptual Model of Groundwater Flow ........................................................................................... 11

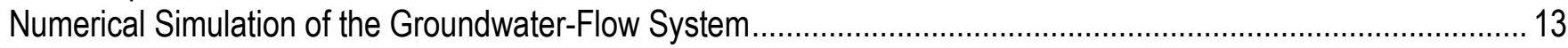

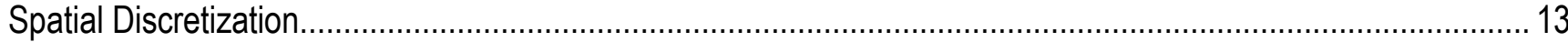

Boundary Conditions and Implementation of MODFLOW Packages ............................................................. 14

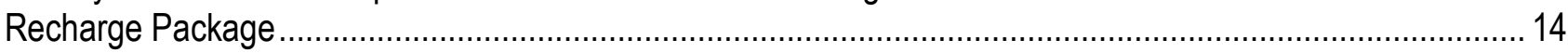

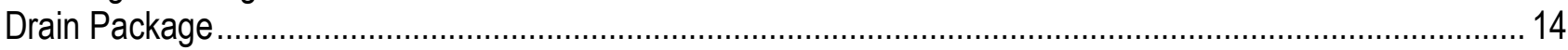

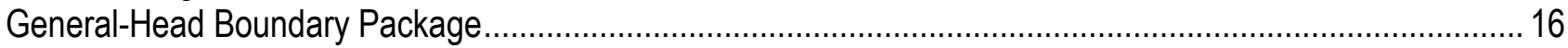

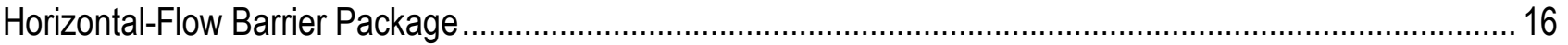

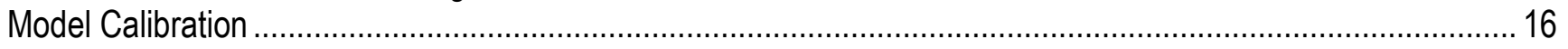

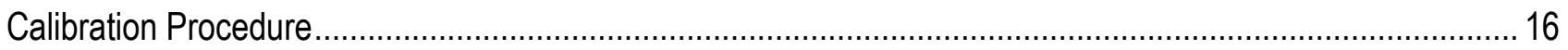

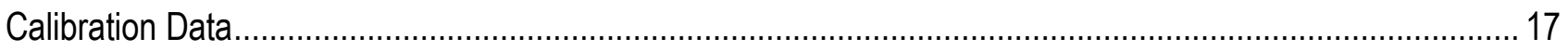

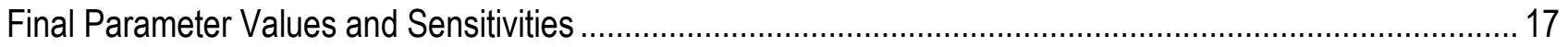

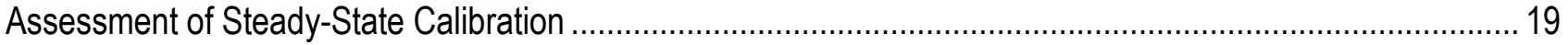

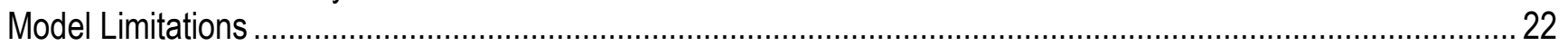

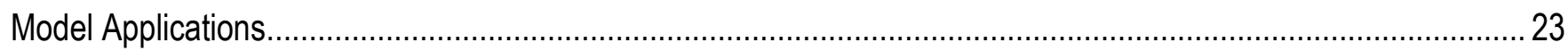

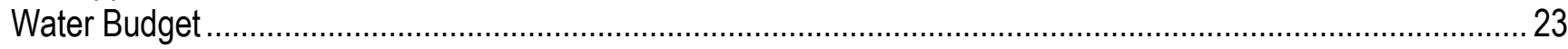

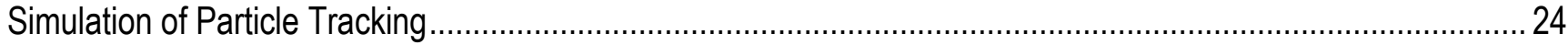

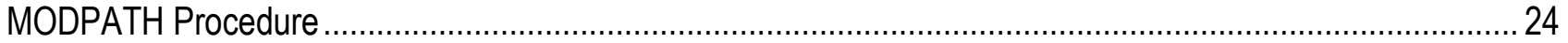

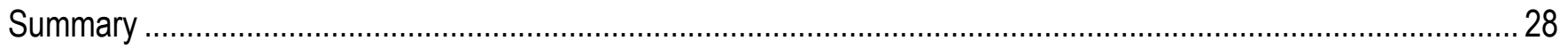

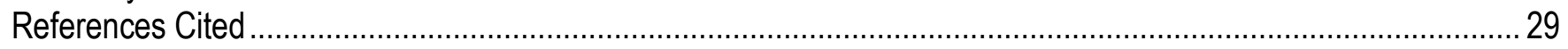

\section{Figures}

Figure 1. Map showing location of study area, Puget Sound Naval Shipyard, Naval Base Kitsap,

Bremerton, Washington

Figure 2. Map showing recharge to model cells in the active domain, Puget Sound Naval Shipyard,

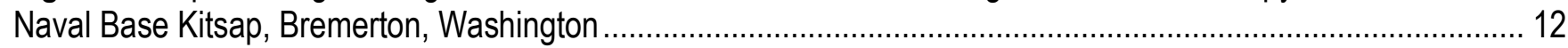

Figure 3. Example cross-section showing hydrogeologic units and model cells along column 55 ....................... 13

Figure 4. Map showing boundary conditions for the groundwater flow model, Puget Sound Naval Shipyard, Naval Base Kitsap, Bremerton, Washington

Figure 5. Graph showing simulated and measured water-level altitudes for the groundwater flow model, Puget Sound Naval Shipyard, Naval Base Kitsap, Bremerton, Washington

Figure 6. Map showing water-level residuals and water-level contours for layer 6 for the groundwater flow model, Puget Sound Naval Shipyard, Naval Base Kitsap, Bremerton, Washington ..... 
Figure 7. Map showing forward particle tracking from selected model cells within the shipyard for the groundwater flow model, Puget Sound Naval Shipyard, Naval Base Kitsap, Bremerton, Washington

Figure 8. Map showing backward particle tracking from long-term monitoring wells for the groundwater flow model, Puget Sound Naval Shipyard, Naval Base Kitsap, Bremerton, Washington

\section{Tables}

Table 1. Final parameter values and sensitivities for the groundwater flow model, Puget Sound

Naval Shipyard, Naval Base Kitsap, Bremerton, Washington.

Table 2. Water budget for steady-state groundwater conditions for the groundwater flow model, Puget Sound Naval Shipyard, Naval Base Kitsap, Bremerton, Washington

Table 3. Wells, measured water level altitudes, and model cell assignments used in calibration.

\section{Conversion Factors}

\begin{tabular}{lcl}
\hline \multicolumn{1}{c}{ Multiply } & By & \multicolumn{1}{c}{ To obtain } \\
\hline cubic foot per second $\left(\mathrm{ft}^{3} / \mathrm{s}\right)$ & 0.02832 & cubic meter per second $\left(\mathrm{m}^{3} / \mathrm{s}\right)$ \\
inch (in.) & 2.54 & centimeter $(\mathrm{cm})$ \\
inch (in.) & 25.4 & millimeter $(\mathrm{mm})$ \\
inch per year (in/yr) & 25.4 & millimeter per year $(\mathrm{mm} / \mathrm{yr})$ \\
mile $(\mathrm{mi})$ & 1.609 & millimeter $(\mathrm{mm})$ \\
foot $(\mathrm{ft})$ & 0.3048 & meter $(\mathrm{m})$ \\
foot per day $(\mathrm{ft} / \mathrm{d})$ & 0.3048 & meter per day $(\mathrm{m} / \mathrm{d})$ \\
square mile $\left(\mathrm{mi}^{2}\right)$ & 2.590 & square kilometer $\left(\mathrm{km}^{2}\right)$ \\
\hline
\end{tabular}

Temperature in degrees Celsius $\left({ }^{\circ} \mathrm{C}\right)$ may be converted to degrees Fahrenheit $\left({ }^{\circ} \mathrm{F}\right)$ as follows:

${ }^{\circ} \mathrm{F}=\left(1.8 \mathrm{x}^{\circ} \mathrm{C}\right)+32$.

Temperature in degrees Fahrenheit $\left({ }^{\circ} \mathrm{F}\right)$ may be converted to degrees Celsius $\left({ }^{\circ} \mathrm{C}\right)$ as follows:

${ }^{\circ} \mathrm{C}=\left({ }^{\circ} \mathrm{F}-32\right) / 1.8$.

\section{Datums}

Vertical coordinate information is referenced to the North American Vertical Datum of 1988 (NAVD 88), referred to in this report as "sea level."

Horizontal coordinate information is referenced to the North American Datum of 1983 (NAD 83).

Altitude, as used in this report, refers to distance above or below sea level. 


\title{
Numerical Simulation of Groundwater Flow at Puget Sound Naval Shipyard, Naval Base Kitsap, Bremerton, Washington
}

By Joseph L. Jones, Kenneth H. Johnson, and Lonna M. Frans

\begin{abstract}
Information about groundwater-flow paths and locations where groundwater discharges at and near Puget Sound Naval Shipyard is necessary for understanding the potential migration of subsurface contaminants by groundwater at the shipyard. The design of some remediation alternatives would be aided by knowledge of whether groundwater flowing at specific locations beneath the shipyard will eventually discharge directly to Sinclair Inlet of Puget Sound, or if it will discharge to the drainage system of one of the six dry docks located in the shipyard. A 1997 numerical (finite difference) groundwater-flow model of the shipyard and surrounding area was constructed to help evaluate the potential for groundwater discharge to Puget Sound. That steady-state, multilayer numerical model with homogeneous hydraulic characteristics indicated that groundwater flowing beneath nearly all of the shipyard discharges to the dry-dock drainage systems, and only shallow groundwater flowing beneath the western end of the shipyard discharges directly to Sinclair Inlet.

Updated information from a 2016 regional groundwater-flow model constructed for the greater Kitsap Peninsula was used to update the 1997 groundwater model of the Puget Sound Naval Shipyard. That information included a new interpretation of the hydrogeologic units underlying the area, as well as improved recharge estimates. Other updates to the 1997 model included finer discretization of the finitedifference model grid into more layers, rows, and columns, all with reduced dimensions. This updated Puget Sound Naval Shipyard model was calibrated to 2001-2005 measured water levels, and hydraulic characteristics of the model layers representing different hydrogeologic units were estimated with the aid of state-of-the-art parameter optimization techniques.

The flow directions and discharge locations predicted by this updated model generally match the 1997 model despite refinements and other changes. In the updated model, most groundwater discharge recharged within the boundaries of the shipyard is to the dry docks; only at the western end of the shipyard does groundwater discharge directly to Puget Sound. Particle tracking for the existing longterm monitoring well network suggests that only a few wells intercept groundwater that originates as recharge within the shipyard boundary.
\end{abstract}




\section{Introduction}

The Puget Sound Naval Shipyard (PSNS) Complex Superfund site, generally referred to as either the Bremerton Naval Complex or as Naval Base Kitsap Bremerton (in this report, Puget Sound Naval Shipyard, or just "shipyard") lies on the northern shore of Sinclair Inlet in Puget Sound. The shipyard has a long history that includes extensive filling along the shoreline to create a landscape amenable to industrial activity. The fill is comprised of construction and demolition debris, concrete $\mathrm{rub} / \mathrm{le}$, culverts, waste metal, and other unidentified fill materials. This study was undertaken to update an existing model (Prych, 1997) with new hydrogeologic interpretation and recharge estimates, and greater spatial resolution.

\section{Background}

The industrialized portion of the Puget Sound Naval Shipyard in Bremerton, Washington, has been involved in Naval shipbuilding and repair activities since the 1890s. Information about groundwater-flow paths and locations where groundwater discharges near the shipyard is necessary for understanding the fate and transport of subsurface contaminants, which at this site include various volatile organic compounds including trichloroethene (commonly referred to as TCE) and tetrachloroethene (or perchloroethylene, commonly referred to as PCE). Five of the six large ship dry docks along the shoreline of the site are heavily pumped to remove inflow, creating local cones of depression that significantly alter groundwater head gradients, effectively capturing groundwater contaminants from a wide area but also increasing groundwater velocities and thus minimizing travel times for natural attenuation. Potential offsite sources of groundwater contamination also may be captured by dry dock pumping. The current remediation strategy or future remediation plans that may be enacted as new contaminants are discovered would benefit from a better understanding of how groundwater-flow paths and discharge zones are affected by increased development of the site (URS Consultants, Inc., 1994a).

In July 2012, the U.S. Geological Survey (USGS), in cooperation with Naval Facilities Engineering Command-Northwest, began a project to construct and apply a groundwater flow model for the area of PSNS to better understand the historical and potential future migration of VOCs in groundwater. An existing steady-state USGS MODFLOW groundwater-flow model (Prych, 1997) was (1) rediscretized to enhance the spatial resolution by approximately a factor of two; (2) updated with land-use information and recharge boundary conditions that reflect changes to the extent of industrial areas; (3) made consistent with the newly interpreted hydrogeologic framework for a regional groundwater-flow model constructed for the greater Kitsap Peninsula in 2016 (Frans and Olsen, 2016), and (4) calibrated using new groundwater-level data with the benefit of the parameter estimation program (PEST) (Doherty, 2005, 2006). 


\section{Purpose and Scope}

This report describes the construction, calibration, and application of an updated MODFLOW groundwater-flow model for the PSNS. The model is based on a previous model (Prych, 1997), with the addition of hydrogeologic interpretation of the underlying strata, and decreased cell dimensions throughout. Recharge values used by Prych (1997) were recalculated to be consistent with those used for the regional-scale Kitsap Peninsula model (Welch and others, 2014), based on precipitation, surficial geology, and land cover, with further refinements to accommodate smaller cell sizes and to better reflect land cover (particularly impervious areas). Model particle-tracking applications were used to describe overall flow paths within the groundwater-flow system as simulated, and to estimate the contributing recharge area associated with selected monitoring wells.

The report does not address transient (time-varying) conditions such as seasonal variations in groundwater recharge or tidal fluctuations, nor does it discuss the possible influences of these variables under transient conditions.

\section{Previous Work}

An initial assessment of contamination and physical features and ecology of the shipyard and surrounding area was conducted under the CLEAN program (U.S. Navy, 1983), which identified six potentially contaminated sites at the shipyard. A preliminary assessment supplemental report (U.S. Navy, 1990) identified five additional sites. Eight of the 11 sites were recommended for inclusion in a site-inspection study. The site-inspection study, which was the first major study of the shipyard under the CLEAN program, included 12 sites (URS Consultants, Inc., 1992a). As part of the site inspection study, information on stratigraphy and contaminants in soil was collected by boring 79 holes and collecting and analyzing soil samples from the holes. Wells for measuring water levels and collecting water samples were installed in 30 of the holes, and slug tests for estimating horizontal hydraulic conductivity were conducted on 26 of the wells.

A number of individual or groups of sites (called Operable Units) that were the subject of the site-inspection study also have been the subject of numerous follow-up studies (URS Consultants, Inc., 1993a, 1993b, 1993c, 1993d, and 1994b). Most of these studies were conducted to collect additional information on the hydrogeology and degree and extent of contamination in order to determine the human and environmental health risks posed by the contaminants, to decide if remediation work is necessary, and to evaluate the feasibility of different remediation alternatives.

URS Consultants, Inc. (1992b) described a numerical model of groundwater flow and solutetransport in the shipyard and immediate area that was constructed to evaluate effects of general groundwater flow, tidal action, and saltwater intrusion on the fate and transport of subsurface contaminants. This model was constructed using the finite-difference computer code HST3D (Kipp, 1987), which is capable of simulating non-steady flow of a fluid with a nonuniform density. The modeled area was digitized on an $11 \times 17$ rectangular grid of points in each of two layers. Model simulations indicated that much of the groundwater at the shipyard flows to the drainage systems of the dry docks. However, because the dimensions of a model cell were about as large or larger than the dimensions of a typical dry dock, the model was not capable of resolving details of groundwater flow to individual dry docks, except for perhaps to dry dock 6 (DD-6), which is more than 1,000 ft from the other dry docks. Simulations with and without tides indicated that tides do not affect groundwater-flow directions farther than about one grid space (about $700 \mathrm{ft}$ ) inland from the shoreline. Simulated groundwater levels were 0 to $0.81 \mathrm{~m}(0-2.7 \mathrm{ft})$ higher with the density of water in Sinclair Inlet greater than the density of fresh groundwater than with the density of water in Sinclair Inlet equal to the density of fresh groundwater. 
During summer 1994, Prych (1995) measured the quantity and quality of water flowing into and out of the dry docks. Prych used these measurements to estimate the rates of fresh and saline groundwater discharge into each dry dock. These discharges were used to assess the numerical groundwater model of the present study.

A second Remedial Investigation/Feasibility Study RI/FS, for Operable Unit (OU) A, was initiated by the Navy in 1993. Two field investigations were conducted from April to June 1993 and from June to September 1994. The final OU A RI report was published in August 1995 (U.S. Navy, 1995b). The final FS was published in October 1995 (U.S. Navy, 1995c). The Record of Decision for OU A was signed in January 1997 (U.S. Navy, Washington State Department of Ecology, and U.S. Environmental Protection Agency, 1997).

Remedial Investigations (RIs) for OU NSC (March 1993-September 1994, U.S. Navy, 1995a) and OU B (March-July 1994; U.S. Navy, 1996) included collection of groundwater samples from 8 and 31 locations, respectively. These included salinity profiles. A second RI at OU B included collection of groundwater samples from 47 locations during July-November 1995, and 8 locations in July 1995 (URS Consultants, Inc., 2002).

OU B was divided into separate terrestrial and marine units in spring 2000; a final RI report addressing OU B Terrestrial was published in March 2002 (URS Consultants, Inc., 2002). OU C is a petroleum unit being managed under the State of Washington's cleanup program, rather than CERCLA. A steam sparging system was installed at OU C in 1996 and was used until 1998 to recover petroleum product (U.S. Navy, 2002a, 2004). System operation was terminated in response to decreasing product recovery rates. Quarterly monitoring of groundwater in downgradient wells was initiated in January 2001. A Cleanup Action Plan for OU C was approved by the Washington State Department of Ecology (2007). OU D was created in August 2002 comprising a limited portion of the far eastern end of OU B Terrestrial (U.S. Navy, 2004).

Long-term monitoring results (Sealaska, 2015, 2016) include descriptions of the current monitoring wells' construction details, as well as analytical results from ongoing sampling, and trends for contaminant concentrations. The areas that contribute recharge to these wells, and whether the wells are likely to intercept recharge that has passed through known contaminant sources is of ongoing interest.

The model described herein is a revision of the model described in Prych (1997), which covered the same area with a steady-state model comprising 14 layers, 70 rows, and 40 columns. Grid dimensions for the Prych model ranged from 125 to $1,000 \mathrm{ft}$ in the north-south direction and from 47 to $600 \mathrm{ft}$ in the east-west direction, with the smallest dimensions near the dry docks. Layer thickness ranged from 10 to $1,650 \mathrm{ft}$ with the thinnest layers located between $90 \mathrm{ft}$ below to $12 \mathrm{ft}$ above sea level, which includes the dry docks. The layers were homogeneous with horizontal hydraulic conductivity of $10^{-3} \mathrm{ft} / \mathrm{s}$, and vertical hydraulic conductivity of $10^{-7} \mathrm{ft} / \mathrm{s}$.

The water budget for the Prych model with no-flow boundaries on the model perimeter showed discharge to the dry docks was more than twice the estimated recharge from precipitation, with the balance flowing into the dry docks from Puget Sound. Discharge to Puget Sound was less than one-third of recharge from precipitation. Results using specified-head boundaries were similar. Particle-tracking results for the model were used to delineate recharge areas with common discharge areas; with the exception of the western edge of the shipyard, all particles discharged at one of the five dry docks with drainage systems. 
Welch and others (2014) described the hydrogeologic framework, groundwater movement, and water budget of the Kitsap Peninsula, including the area occupied by the shipyard. Building on that work, Frans and Olsen (2016) described the groundwater movement and water budget of the Kitsap Peninsula based on computer modeling. The calibration of that model used water levels from 2007 to 2012. Hydraulic head contours for aquifers were created with steady-state simulations.

\section{Description of the Shipyard and Surrounding Area}

Naval Base Kitsap was created in 2004 by merging the former Naval Station Bremerton with Naval Submarine Base Bangor. The mission of Naval Base Kitsap is to serve as the host command for the Navy's fleet throughout western Puget Sound and to provide base operating services, including support for both surface ships and submarines homeported at Bremerton and Bangor. The area of interest in this study is the PSNS, which occupies a strip of land as wide as $0.6 \mathrm{mi}$ wide that stretches along $1.8 \mathrm{mi}$ of the northern shore of Sinclair Inlet near its mouth, and the offshore area where groundwater from the shipyard may discharge into Sinclair Inlet (fig. 1). The modeled area also includes near-offshore areas and most of the peninsula occupied by the city of Bremerton in order to provide the model with suitable hydrologic boundaries. 


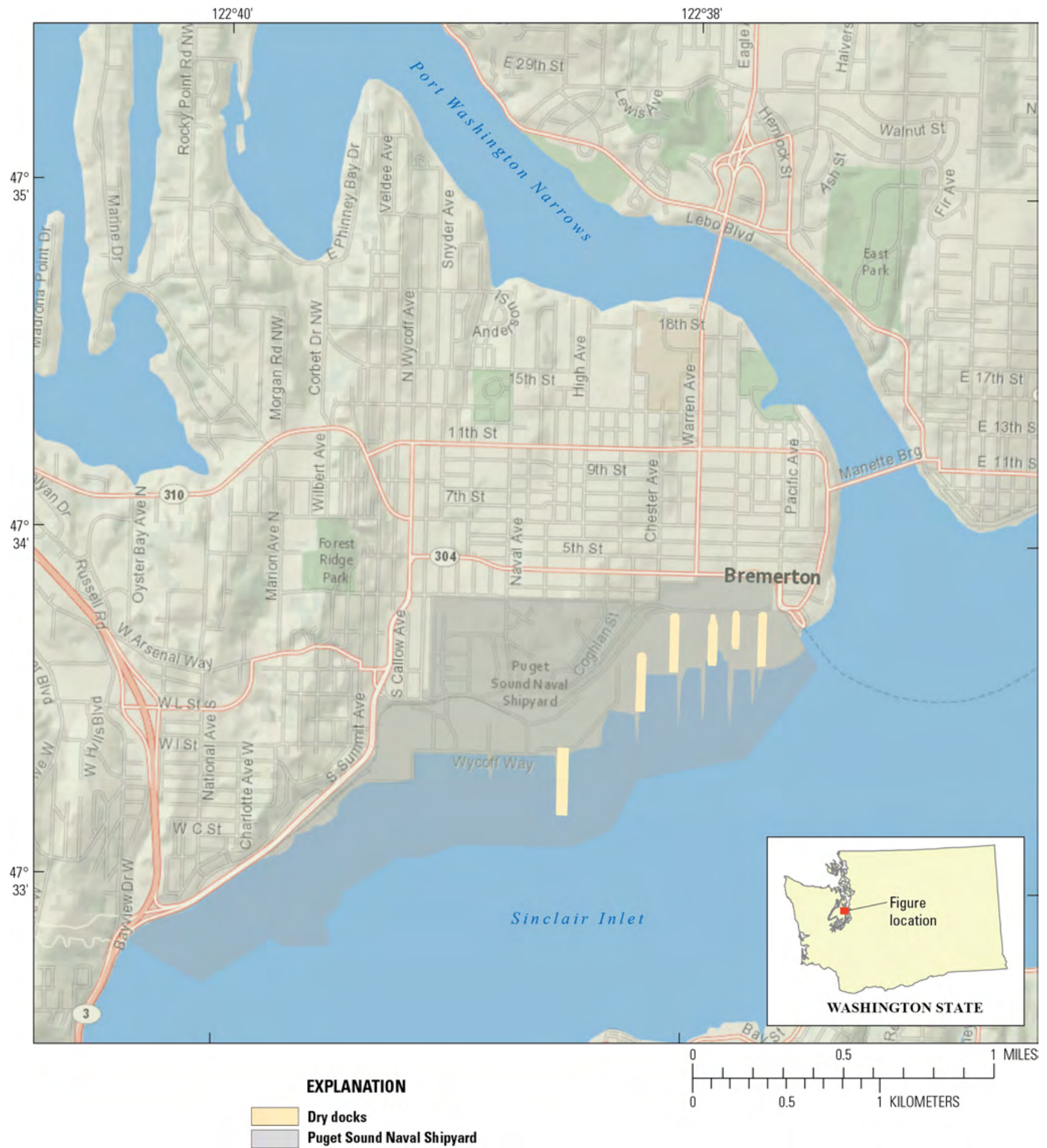

Figure 1. Map showing location of study area, Puget Sound Naval Shipyard, Naval Base Kitsap, Bremerton, Washington. 
The peninsula upon which the shipyard and the city of Bremerton are located is about 3 mi long in the east-west direction and about $2 \mathrm{mi}$ wide in the north-south direction, and is part of the larger Kitsap Peninsula. The peninsula is bordered on the south, east, and north by various bays and inlets of Puget Sound. Land-surface altitudes on the peninsula range from sea level to a maximum of about $240 \mathrm{ft}$ above sea level on north-south trending hills that form a drainage divide on the western side of the peninsula. Land-surface altitudes east of these hills are mostly between 50 and $150 \mathrm{ft}$. Nearly all land on the peninsula has been developed, and the entire peninsula is served by public-water supplies and a sanitary sewer system, and many areas have storm drains. There are no perennial streams on the peninsula.

Sinclair Inlet is deepest near its mouth, where it is about $70 \mathrm{ft}$ deep at mean tide. The inlet is shallowest at its western end, where large mud flats are exposed at low tide. Typical depths in front of the piers and dry docks of the shipyard are about $45 \mathrm{ft}$, and typical depths in Port Washington Narrows on the eastern side of the peninsula are about $30 \mathrm{ft}$. Tides in Puget Sound and Sinclair Inlet are diurnal, with two unequal high and two unequal low tides during each tidal cycle (about $24.8 \mathrm{~h}$ ). The mean tide range (difference between mean lower low and mean higher high water) is about $12 \mathrm{ft}$. Salinity of the water in the inlet is typically about 30 parts per thousand, but it varies a few parts per thousand both spatially and temporally. Stratification of saline water is slight, probably because no large freshwater streams discharge to the inlet or elsewhere nearby to Puget Sound.

The study area has a temperate marine climate with warm, dry summers, and cool, wet winters. Temperatures are moderated by the Pacific Ocean and Puget Sound. The ocean provides an abundant supply of moisture for winter storms that typically approach the area from the southwest. Mean annual precipitation (average annual precipitation for 1981-2010) is 56.4 in. at Bremerton (National Oceanic and Atmospheric Administration, 2014). The distribution of precipitation varies throughout the year at Bremerton. Summers (June-August) are typically dry with a mean total precipitation of 3.8 in. and winters (December-February) are wetter than summers with a mean total precipitation of 25 in. Mean monthly temperature (average monthly temperature for 1981-2010) at Bremerton ranges from about $40^{\circ} \mathrm{F}$ in December to about $66^{\circ} \mathrm{F}$ in August (National Oceanic and Atmospheric Administration, 2014). 


\section{Groundwater-Flow System}

This section describes the hydrogeologic units that constitute the groundwater-flow system in the model area and includes discussions of recharge, flow directions, and discharge to dry docks. This information was used to construct and calibrate the numerical model and is based on the work of Prych (1997), Welch and others (2014), Frans and Olsen (2016), and information provided by the Naval Facilities Engineering Command-Northwest.

\section{Geologic Setting}

The shipyard and surrounding area are located in the Puget Sound Lowlands, a north-south trending structural basin that is partly filled with unconsolidated glacial and interglacial deposits. The most recent advance and retreat of continental glaciers in the Pleistocene epoch of the Quaternary Period left behind more than 3,000 ft of unconsolidated deposits in the Puget Lowland (Jones, 1996). The Puget Lobe of the Cordilleran ice sheet advanced and retreated several times into the Puget Lowland from the mountains of British Columbia during the Pleistocene and left behind a complex sequence of alternating glacial and interglacial sediments. The Vashon Stade of the Fraser Glaciation was the most recent and extensive of the major advances. Glacial sediment typically includes (in order of deposition) outwash sand and gravels deposited by the advancing ice; glacial till (hard and poorly sorted mixture of clay, silt, sand, and gravel) and ice-contact material deposited beneath and adjacent to the ice; and outwash sand and gravels at the top of the sequence deposited by the retreating ice.

Each major glacial interval was followed by an extended interglacial period during which fluvial, lacustrine, bog, and marsh deposition dominated. Interglacial deposits typically comprise clay, silt, or discontinuous lenses of sand and gravel or peat. Underlying the unconsolidated glacial and interglacial deposits in the Puget Lowland are Tertiary bedrock units comprised mainly of sedimentary and volcanic rocks.

Total thickness of glacial and interglacial deposits near the shipyard ranges from 0 to about $1,800 \mathrm{ft}$ (Jones, 1996). The most common geologic units exposed at land surface in the Bremerton area are Vashon till and outwash. Bedrock (marine and non-marine sedimentary rocks and volcanic rocks) is exposed at land surface about $2 \mathrm{mi}$ north of the shipyard and also in another area about $2 \mathrm{mi}$ west of the shipyard. In addition to the natural sediments, a large part of the industrial area of shipyard is built on fill that is as much as $50 \mathrm{ft}$ thick near the shoreline (URS Consultants, Inc., 1994a). The fill consists of construction and demolition debris, other waste material, and natural sediments from nearby excavations. A low-permeability unit consisting mostly of early Vashon glaciolacustrine silt and clay is present beneath the fill. 


\section{Hydrogeologic Units}

Hydrogeologic units, consisting of aquifers and confining units were defined for this study on the basis of lithologic (depositional facies, grain size, and sorting) and hydrologic (hydraulic conductivity and unit geometry) characteristics (Welch and others, 2014). Glacial deposits generally are heterogeneous, and although a glacial aquifer may be composed primarily of sand or gravel, it locally may contain varying amounts of clay or silt. Conversely, a confining unit composed predominantly of silt or clay may contain local lenses of coarse material.

Unconfined and confined conditions are present in the groundwater-flow system and affect the movement and storage of groundwater in the study area. Unconfined conditions occur when the upper surface of the saturated zone (water table) is at atmospheric pressure and the water table is free to rise and decline, filling and draining pore space, respectively, in response to changes in groundwater recharge and discharge. Confined conditions occur when groundwater pressure exceeds atmospheric pressure due to the presence of a less permeable overlying unit that constrains the thickness of the saturated zone. Transient changes in fluid pressure or head under confined conditions in response to groundwater recharge and discharge are governed by the compressibilities of the fluid and the skeletal matrix of the hydrologic units and do not result in filling or draining pore space.

Ten hydrogeologic units are recognized in the study area including bedrock, which is modeled as a no-flow boundary; their lithologic and hydraulic characteristics are described below.

- The Vashon till confining unit (Qvt) is present at land surface throughout much of the study area. This low-permeability unit is composed of a dense mix of sand and gravel in a clay matrix. The unit is absent at land surface in some areas due to erosion by ephemeral streams. The average thickness of Qvt within the active model boundary is $42 \mathrm{ft}$.

- The Vashon advance aquifer (Qva) consists of well-sorted sand, or sand and gravel, with lenses of silt and clay that underlies the Qvt, and also is exposed at the surface at several locations. Confined groundwater conditions are present where the unit is saturated fully and is overlain by Qvt, and unconfined conditions are present at locations where the Qva is exposed at land surface. The average thickness of Qva within the active model boundary is $65 \mathrm{ft}$.

- Beneath Qva is the upper confining unit (QC1), which is a thick and laterally extensive lowpermeability unit consisting mostly of early Vashon glaciolacustrine silt and clay (Kitsap Clay) and underlying interglacial deposits of silt, sand, and gravel with numerous lenses of silt and clay or silty peat. The average thickness of QC1 within the active model boundary is $91 \mathrm{ft}$.

- The sea-level aquifer (QA1) is present in the subsurface throughout the study area and consists primarily of glacial sand and gravel, with silt interbeds. There are no surface exposures of QA1 within the study area, and groundwater in this aquifer is under confined conditions. The average thickness of QA1 within the active model boundary is $99 \mathrm{ft}$.

- The middle confining unit (QC2) is a low-permeability unit underlying QA1, consisting of interglacial sandy silty clay and glacial sand and gravel, with significant amounts of silt and clay layers. The unit is present in the subsurface throughout the study area, and the average thickness of QC2 within the active model boundary is $136 \mathrm{ft}$. 
- The glaciomarine aquifer (QA2) is present in the subsurface throughout the study area and ranges in composition from sand and gravel to silt, with occasional shell fragments. There are no surface exposures of QA2 in the study area, and groundwater in this aquifer is under confined conditions. The average thickness of QA2 within the active model boundary is $161 \mathrm{ft}$.

- The lower confining unit (QC3) is a low-permeability unit composed of clay and silt, with some gravel. The unit is present in the subsurface throughout the study area, and the average thickness of QC3 within the active model boundary is $165 \mathrm{ft}$.

- The deep aquifer (QA3) is present in the subsurface throughout the study area and consists primarily of sand and gravel with silt interbeds. There are no surface exposures of QA3 within the study area, and groundwater in this aquifer is under confined conditions. The average thickness of QA3 within the active model boundary is $170 \mathrm{ft}$.

- The basal confining unit (QC4) is a low-permeability unit composed of clay and silt with some gravel. The unit is present in the subsurface throughout the study area, and the average thickness of QC4 within the active model boundary is $271 \mathrm{ft}$.

- Bedrock (BR) is present in the subsurface throughout the study area and consists of marine and non-marine sedimentary rocks and volcanic rocks. The bedrock unit crops out in the northern part of the study area.

In addition to the hydrogeologic units, a large part of the shipyard is built on artificial fill. Welch and others (2014) did not map this areally small Fill unit for the regional Kitsap model, instead mapping the unit as QC1 in that area. A Fill unit was added to the updated model constructed in this study by converting appropriate QC1 cells in the regional model into Fill cells in the updated model. The areal extent of the Fill unit was taken from P.J. Hauessler (U.S. Geological Survey, unpub. data, 2007). The Fill unit was assigned to model layers from the ground surface down through layer 7.

\section{Hydraulic Conductivity}

Welch and others (2014) reported median estimated horizontal hydraulic conductivities for hydrogeologic units based on specific-capacity data from well drillers' reports, and Frans and Olsen (2016) reported median model-generated hydraulic conductivities for the hydrogeologic units within the Kitsap Peninsula study area. Those values, respectively, are, in feet per day (-- indicates not reported): Qvt (--, 3.14), Qva (51, 24.57), QC1 (--, 0.83); QA1 $(38,12.26)$; QC2 (--, 0.98); QA2 (35, 7.90); QC3 ($-, 0.81)$; QA3 $(32,19.64)$. These values were used to aid in evaluating model-calibrated conductivity estimates. 


\section{Conceptual Model of Groundwater Flow}

Recharge to the groundwater-flow system occurs primarily due to infiltration of natural precipitation; in this model, recharge from other sources such as outdoor use of domestic water is considered negligible. The long-term average annual precipitation at Bremerton, Washington, is 56.37 in/yr for 1981-2010 (Welch and others, 2014). Areally distributed precipitation amounts were used by Welch (2014) along with surficial geology (glacial outwash or glacial till) and land cover (with tree canopy, without tree canopy, or urban/bedrock) using the regression equations developed by Bidlake and Payne (2001) to calculate estimated mean annual recharge from precipitation for use in the regional Kitsap peninsula groundwater-flow model (Frans and Olsen, 2016). Those values were re-discretized to match the cell sizes used in this updated PSNS model (fig. 2). Regional groundwater flow also enters into the model area from the west; the magnitude of this flow was estimated using output from the Kitsap Peninsula model (Frans and Olsen, 2016).

Groundwater-flow directions are reflective of the general topography of the model area-from the high ground to the west and north, southeastward toward Sinclair Inlet and Port Washington Narrows. Prych (1997) contoured measured water levels to demonstrate that the dry docks locally capture southeast-trending flow as discharge to the dry-dock drains.

The dry docks generally are drained except when flooded to float a vessel. Dry docks 1 and 3 through 6 are equipped with drains on the sides and headwall and beneath the bottom to remove any groundwater that seeps in, and their bottom altitudes range from -16.5 ft (dry dock 3 ) to $-45.5 \mathrm{ft}$ (dry dock 6). Such a large altitude difference between the dry-dock bottom and the surrounding terrain creates steep groundwater potentiometric head gradients that alter the natural groundwater-flow directions; the gradients are steep toward the dry docks (except dry dock 2), which causes groundwater in the immediate vicinity of a dry dock to flow directly to that dry dock. Prych (1997) used forward particle-tracking analyses to demonstrate that "nearly all groundwater flowing through the shipyard discharges to the drainage systems of the dry docks." 


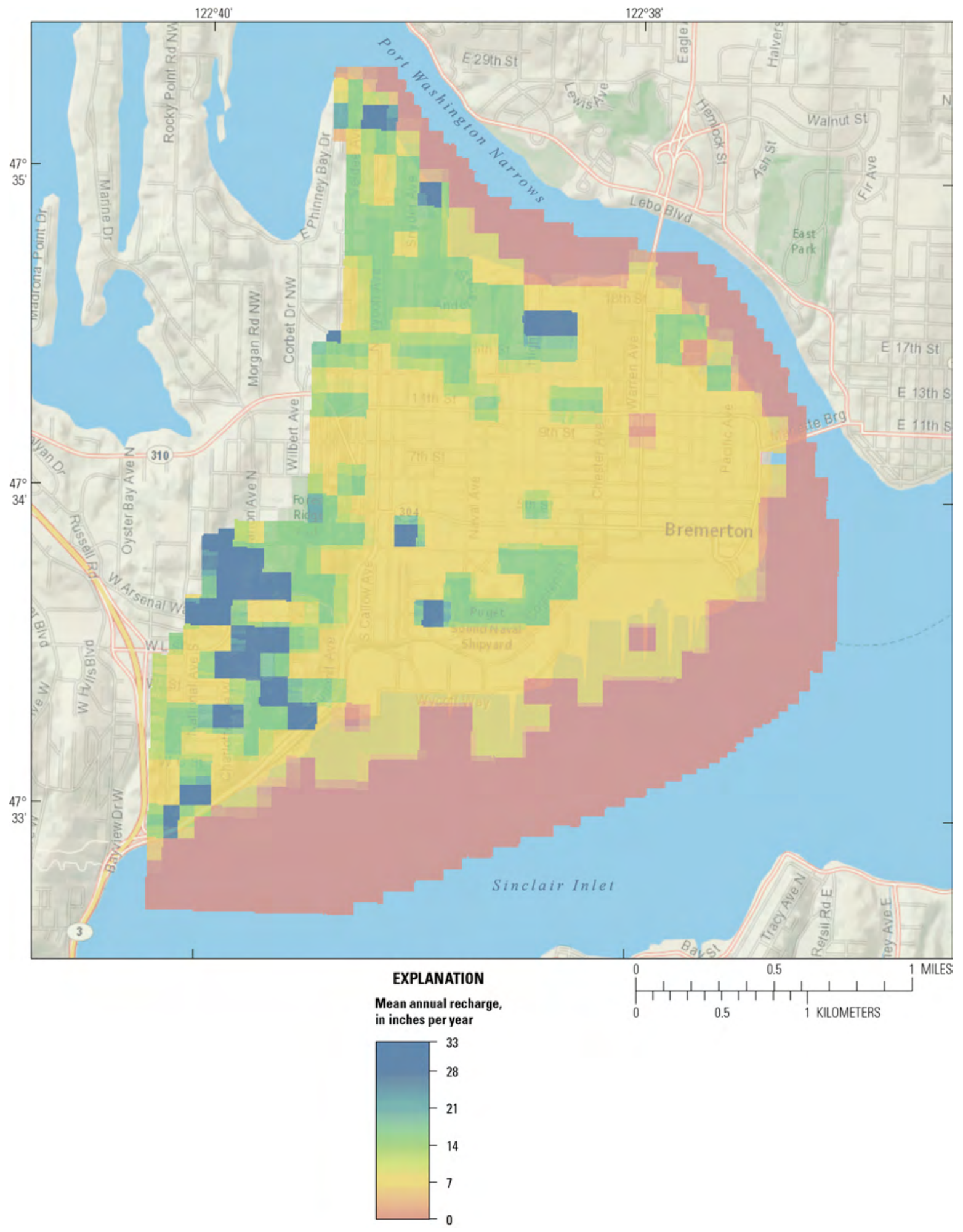

Figure 2. Map showing recharge to model cells in the active domain, Puget Sound Naval Shipyard, Naval Base Kitsap, Bremerton, Washington. 


\section{Numerical Simulation of the Groundwater-Flow System}

This revision of the Prych steady-state model with updated areal recharge and inflow from the regional flow system, hydrogeology, and cell and layer dimensions also was calibrated to steady-state conditions; in this case, measured hydraulic heads for 2001-2005. The model used was MODFLOWNWT (Niswonger and others, 2011).

\section{Spatial Discretization}

The geographic extent of the updated numerical finite-difference model is the same as that defined by Prych (1997), but the number of model rows is increased from 70 to 104 , and the number of columns is increased from 40 to 141 . Ranges in row heights are reduced from 125-1,000 ft to 55-240 ft. Ranges in column widths are reduced from $47-600 \mathrm{ft}$ to $26-300 \mathrm{ft}$.

The updated model includes 22 layers compared to Prych's (1997) 14 model layers, and the tops or bottoms of the updated model layers are redefined so that each layer lies within a single hydrogeologic unit. Overall, the nine natural hydrogeologic units plus the fill unit were divided into 22 layers, with the uppermost hydrogeologic units having the most model layers; figure 3 shows a northsouth cross section of the model showing hydrogeologic unit assignments and cell boundaries.

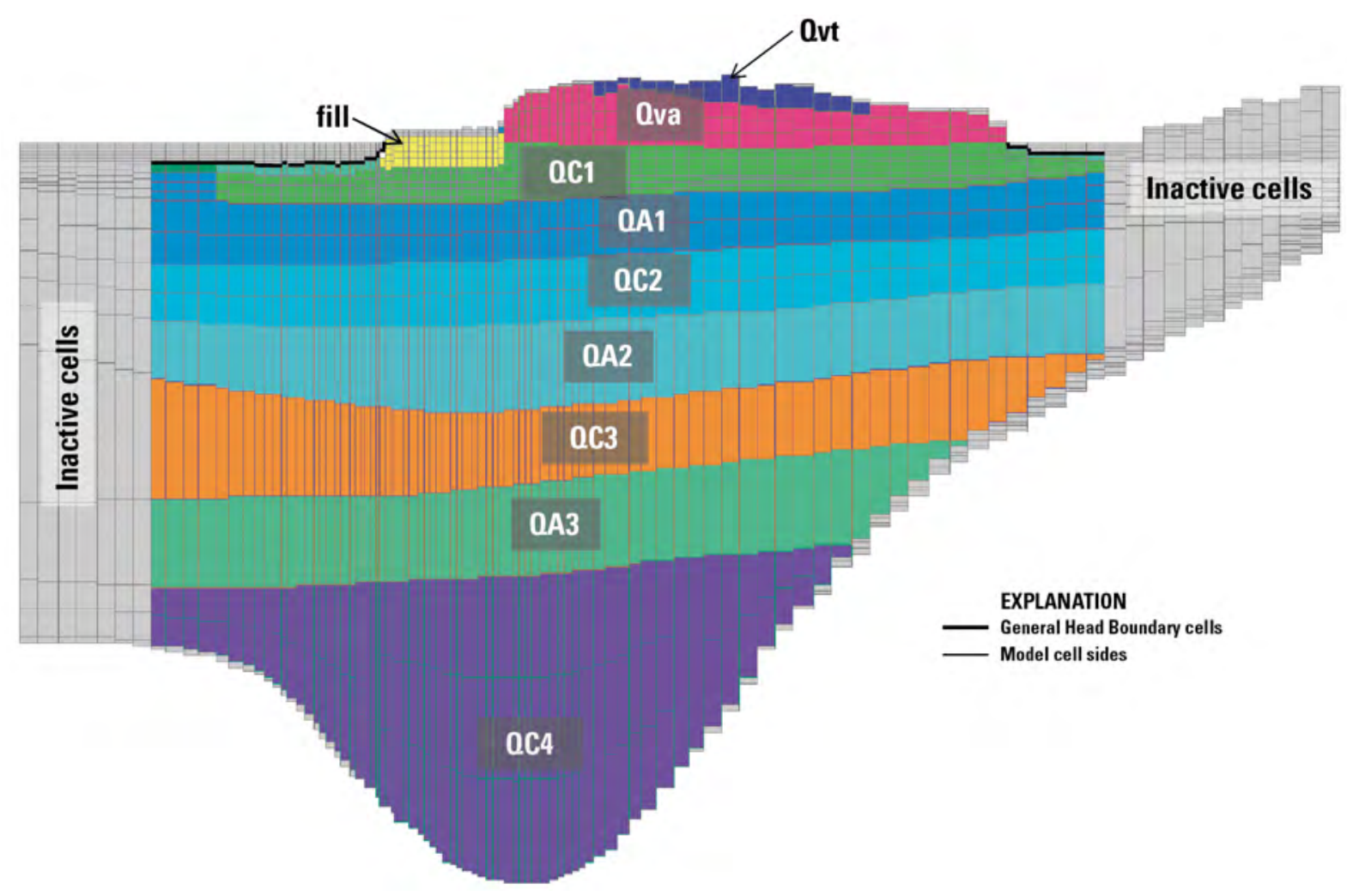

Figure 3. Example cross-section showing hydrogeologic units and model cells along column 55. 


\section{Boundary Conditions and Implementation of MODFLOW Packages}

Boundary conditions (fig. 4) were applied to model cells to represent conditions at locations where water enters or exits the groundwater-flow system. This model of the Puget Sound Naval Shipyard uses several MODFLOW packages (Niswonger and others, 2011) to represent these conditions: the Recharge Package for areal groundwater recharge due to precipitation; the General Head Boundary (GHB) Package for groundwater discharge to marine water, and groundwater inflow at the western edge of the active model domain; the Drain Package for groundwater discharge to the six dry docks, and in areas where low hydraulic conductivity units outcrop and route groundwater to the land surface; and the Horizontal-Flow Barrier package (HFB) (Hsieh and Freckleton, 1993) to represent impediments to groundwater discharge from sheet-pile cutoff walls and concrete bulkheads. No-flow cells were used in the interior of the dry docks as they are empty space. Additionally, because the model is within the domain of a groundwater model of the Kitsap Peninsula (Frans and Olsen, 2016), simulated hydraulic heads from the Kitsap model were used with the GHB Package to help define groundwater inflow at the western edge of the active model domain where Prych (1997) used surfacewater divides to infer no-flow boundaries. The model was assigned no-flow boundaries on the bottom of the model domain (beneath QC4, representing bedrock). Figures 2 and 4 show the distribution of the various boundary condition cells.

\section{Recharge Package}

The Recharge Package $(\mathrm{RCH})$ of MODFLOW was used to simulate areal groundwater recharge from precipitation. Recharge (in units of feet per day) was applied as a specified flux to the uppermost active cell. Precipitation is the dominant source of water recharging the groundwater system in the study area, and variations in recharge are related to spatial and temporal variations in precipitation, the permeability of surficial hydrogeologic units, and land-cover characteristics. The distribution of annual recharge from precipitation in the study area (Welch and others, 2014) was estimated by applying precipitation-recharge relations based on regression equations developed for areas in Puget Sound, Washington (Bidlake and Payne, 2001) that incorporate the effects of surficial hydrogeology and tree canopy characteristics. Using those equations, the groundwater system received an average (1980-2010) of 7.53 in. of recharge from precipitation annually.

\section{Drain Package}

The model simulates groundwater discharge to the dry-dock drainage systems from model cells that are adjacent to dry-dock sidewalls or headwalls and from cells beneath dry-dock floors using the Drain Package of MODFLOW. The drain altitude for a cell adjacent to a dry-dock wall is assumed equal to the altitude of the mid-point of the cell, whereas the drain altitude for a cell beneath a dry-dock floor is assumed to equal the altitude of the top of the concrete floor. Drains also were placed in areas where low hydraulic conductivity units outcrop at the surface to simulate the routing of rejected recharge in those areas. 


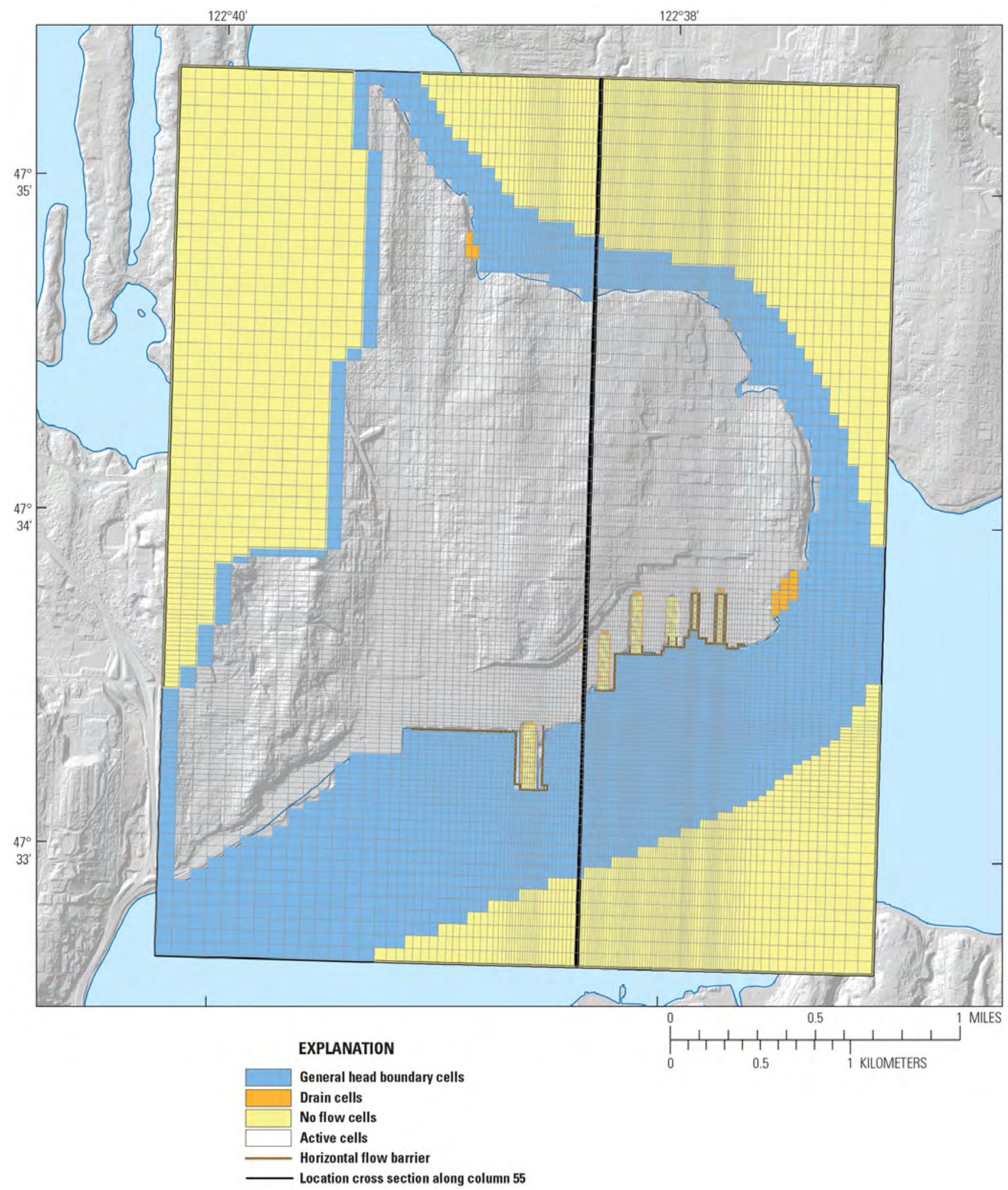

Figure 4. Map showing boundary conditions for the groundwater flow model, Puget Sound Naval Shipyard, Naval Base Kitsap, Bremerton, Washington. 


\section{General-Head Boundary Package}

Cells in contact with salt water (along Sinclair Inlet and Port Washington Narrows) are cells that conceptually discharge more, or less, groundwater depending on the relative heads of the groundwater system at the cell and the equivalent fresh-water head of salt water at that location. The General Head Boundary (GHB) package provides the capability to simulate this head-dependent flow, and is applied at all cells in contact with salt water. The specified head for model cells representing the sea floor in Puget Sound was set to fresh-water equivalent heads (above sea level). Freshwater equivalent heads above sea level were set equal to 0.023 times the height of the saltwater column above the cell (van Heeswijk and Smith, 2002, p. 39).

GHB cells also were used along the western edge of this model to allow groundwater inflow across boundary cells where Prych (1997) used no-flow conditions assuming surface-water divides could reasonably infer a groundwater divide. Hydraulic head values were specified in these GHB cells using output from regional model of the Kitsap Peninsula (Frans and Olsen, 2016).

\section{Horizontal-Flow Barrier Package}

The sheet-pile cutoff walls beneath the dry docks and the subsurface parts of shoreline bulkheads impede the horizontal flow of groundwater. This phenomenon is simulated by using the HorizontalFlow Barrier (HFB) Package (Hsieh and Freckleton, 1993). HFBs increase the resistance to horizontal flow between two adjacent cells in a layer. HFBs were placed in the model at the locations of the bulkheads and cutoff walls shown in Prych (1997).

\section{Model Calibration}

Model calibration is the adjustment of model parameter values within limits so that the differences (residuals) between measured and simulated groundwater levels are minimized with respect to an objective function, here, the sum of squared weighted residuals. Calibration is assessed by examining how well simulated match measured water-level altitudes.

\section{Calibration Procedure}

The model was calibrated using a combination of traditional trial-and-error adjustment of parameter values and the Parameter ESTimation program (PEST) (Doherty, 2005, 2006). PEST was used to adjust the values of the model parameters (horizontal and vertical hydraulic conductivities of each hydrogeologic unit; and drain, HFB, and GHB conductances) between model calibration runs repeatedly until the differences in measured and simulated water-level altitudes attain minimal sum of squared weighted residuals. Parameter values were constrained within PEST similar to the bounds given to the larger regional Kitsap model. During the calibration process, trial and error was used to establish five Fill units each with homogenous conductivities that allowed the best fit for the water level data. Pilot points and zonation were not used; the Fill units are similar to zones but modeled as individual hydrogeologic units with uniform conductivities. 


\section{Calibration Data}

The model was calibrated to best simulate average measured water-level altitudes in monitoring (non-pumping) wells that were measured during 2001-2005. There were 170 wells in 152 unique model cells. Of these model cells, 118 were assigned to the Fill (layers 4-7), 11 cells were assigned to Qva (layers 1-10), 16 to QC1 (layers 4-12), 5 to QA1 (layers 11-14), and 2 to QC2 (layers 15-16). Measured water-level altitudes ranged from 37.38 to $-56.82 \mathrm{ft}$ (table 3, at back of report).

Each of the water-level altitudes was assigned a weight. Weights are assumed to be proportional to the inverse of the standard deviation of the measurement error (Doherty, 2005; Hill and Tiedeman, 2007), which is problematic to quantify for wells used in this study due to differing or inconsistent datacollection methods and documentation of variables such as land-surface altitude or vertical datum. Some land-surface altitudes were necessarily defaulted to the LiDAR land-surface altitude used for the model, which was obtained through the Puget Sound LiDAR Consortium (2000). Weightings, therefore, were assigned using professional judgment on a scale from 0.25 to 10, with PEST using the values as relative inverse weights. Accurate, repeated observations, with little variation of water-level altitude were assigned a value of 10; wells with greater variability were assigned values of 4.5, and wells with few measurements or comparatively large variability, were assigned 3 . Weighting values of $1,0.5$, and 0.25 were used for wells with high variability.

\section{Final Parameter Values and Sensitivities}

The ability to estimate a parameter value during the calibration process is related to the sensitivity of simulated hydraulic head to changes in the parameter value. For example, if a parameter has a high sensitivity, the observation data effectively estimate the parameter value. For parameters with low sensitivity, changes in the parameter value have little effect on the model-calibration process. Insensitive parameters may or may not be close to their corresponding field values and are not likely to be estimated accurately during the parameter-estimation process.

Relative composite sensitivities are a measure of composite changes in model outputs that are caused by small changes in the value of a modeled parameter (Doherty, 2005). For a given modeled parameter, the larger the value of the associated relative composite sensitivity, the more sensitive the model is to that parameter. Relative composite sensitivities were calculated and analyzed for all parameters used in the model-calibration process (table 1). The parameters with the highest sensitivities were the horizontal and vertical hydraulic conductivities of the Qva and QC1 units, and the horizontal conductivity of Fill unit 3. 
Table 1. Final parameter values and sensitivities for the groundwater flow model, Puget Sound Naval Shipyard, Naval Base Kitsap, Bremerton, Washington.

\begin{tabular}{|c|c|c|c|c|c|}
\hline Parameter & Value & Sensitivity & Parameter & Value & Sensitivity \\
\hline \multicolumn{3}{|c|}{ Horizontal hydraulic conductivity, in feet per day } & Fill 3 & $1.00 \times 10^{-6}$ & $1.22 \times 10^{-3}$ \\
\hline Qvt & 3.99068 & $8.87 \times 10^{-2}$ & Fill 4 & 11.31 & $2.46 \times 10^{-3}$ \\
\hline Qva & 29.0836 & 1.01 & Fill 5 & 0.39 & $6.92 \times 10^{-2}$ \\
\hline QC1 & 0.203648 & 0.978 & \multicolumn{3}{|c|}{ Drain conductance, in feet per day } \\
\hline QA1 & 1,000 & 0.60 & Surface drains & 100 & $2.42 \times 10^{-4}$ \\
\hline QC2 & $5.60 \times 10^{-5}$ & $1.92 \times 10^{-5}$ & Dry dock 1 & 85,000 & $4.42 \times 10^{-3}$ \\
\hline QA2 & 0.358813 & $3.44 \times 10^{-2}$ & Dry dock 3 & $8,419.14$ & $2.99 \times 10^{-3}$ \\
\hline QC3 & $1.22 \times 10^{-4}$ & $2.34 \times 10^{-5}$ & Dry dock 4 & $1.00 \times 10^{6}$ & $2.52 \times 10^{-4}$ \\
\hline QA3 & 2.04916 & $1.51 \times 10^{-6}$ & Dry dock 5 & $1.00 \times 10^{6}$ & $4.84 \times 10^{-4}$ \\
\hline QC4 & $4.81 \times 10^{-2}$ & $9.49 \times 10^{-6}$ & Dry dock 6 & $1.00 \times 10^{6}$ & $3.11 \times 10^{-3}$ \\
\hline Fill 1 & $5,088.16$ & 0.38 & \multicolumn{3}{|c|}{ General head boundary conductance, in feet per day } \\
\hline Fill 2 & 313.274 & $2.39 \times 10^{-2}$ & Puget Sound & $1.52 \times 10^{8}$ & $2.53 \times 10^{-5}$ \\
\hline Fill 3 & 13.2424 & 0.94 & Qvt & 0.25 & $3.82 \times 10^{-3}$ \\
\hline Fill 4 & 100 & 0.32 & Qva & $4.98 \times 10^{-2}$ & $3.43 \times 10^{-3}$ \\
\hline Fill 5 & 10,000 & $1.68 \times 10^{-2}$ & QC1 & 53.123 & 0.47 \\
\hline \multicolumn{3}{|c|}{ Vertical hydraulic conductivity, in feet per day } & QA1 & 1.96 & $1.21 \times 10^{-2}$ \\
\hline Qvt & 0.40 & $7.34 \times 10^{-3}$ & QC2 & $7.19 \times 10^{-4}$ & $2.33 \times 10^{-5}$ \\
\hline Qva & $2.37 \times 10^{-2}$ & 0.74 & QA2 & 12.95 & $1.32 \times 10^{-2}$ \\
\hline QC1 & $5.78 \times 10^{-2}$ & 1.28 & QC3 & 15.29 & $2.03 \times 10^{-5}$ \\
\hline QA1 & 100 & $5.17 \times 10^{-2}$ & QA3 & 780.8 & 0.32 \\
\hline QC2 & $2.43 \times 10^{-3}$ & $4.62 \times 10^{-2}$ & QC4 & 6.44 & $01.15 \times 10^{-5}$ \\
\hline QA2 & 0.10 & $7.57 \times 10^{-4}$ & \multicolumn{3}{|c|}{ Horizontal flow barrier conductance, in feet per day } \\
\hline QC3 & $1.90 \times 10^{-6}$ & $1.78 \times 10^{-4}$ & HFB & $2.47 \times 10^{-8}$ & $4.95 \times 10^{-5}$ \\
\hline QA3 & 1.44 & $1.84 \times 10^{-5}$ & & & \\
\hline QC4 & 0.103811 & $1.51 \times 10^{-6}$ & & & \\
\hline Fill 1 & 11.06 & $2.47 \times 10^{-3}$ & & & \\
\hline Fill 2 & $1.15 \times 10^{-2}$ & 0.49 & & & \\
\hline
\end{tabular}




\section{Assessment of Steady-State Calibration}

The results of the calibration were assessed by examining the mean and the root mean-square error (RMSE) of the difference of measured and simulated water-level altitudes (residuals). The mean of residuals represents the average difference between all measured and simulated values (residuals), and the sign of the mean of residuals (bias) indicates whether the model is over- or under-predicting values (negative and positive mean of residuals, respectively). The RMSE of weighted residuals provides a measure of variation that considers measurement accuracy. The RMSE of the difference between simulated and measured hydraulic heads in the observation wells, divided by the total range in water levels in the groundwater system (Anderson and Woessner, 1992, p. 241), also should be less than 10 percent to be considered acceptable (Drost and others, 1999).

The final calibration resulted in a mean residual value of $1.15 \mathrm{ft}$, indicating the model slightly underpredicts water-level altitudes for the area. Given that the total range of average measured groundwater levels is $94.2 \mathrm{ft}$, the final calibration RMSE of $9.08 \mathrm{ft}$ is 9.6 percent of the total range. The RMSE divided by the total range of values is less than 10 percent, indicating an acceptable model fit (Drost and others, 1999).

A plot of measured and simulated groundwater-level altitudes provides a useful graphical assessment of model calibration (fig. 5). Measured and simulated values should plot close to a line with a slope of 1.0 and an intercept of zero. This diagonal line represents perfect agreement between measured and simulated values (line of equal measured and simulated values), and the magnitude of the residual (difference between measured and simulated values) is reflected in the distance of the value above or below the line. Positive residuals (measured value is greater than simulated value) and negative residuals (measured value is less than simulated value) plot below and above the line, respectively. Measured and simulated values are shown in figure 5. The model did not simulate the exceptionally high or exceptionally low measured values well.

The results of the calibration also were evaluated by displaying the simulated water levels (heads) spatially (fig. 6), along with the residuals for each well. Simulated water-level altitudes indicate that the model reasonably simulated groundwater conditions, and the spatial distribution of the residuals does not indicate any major patterns of bias. 


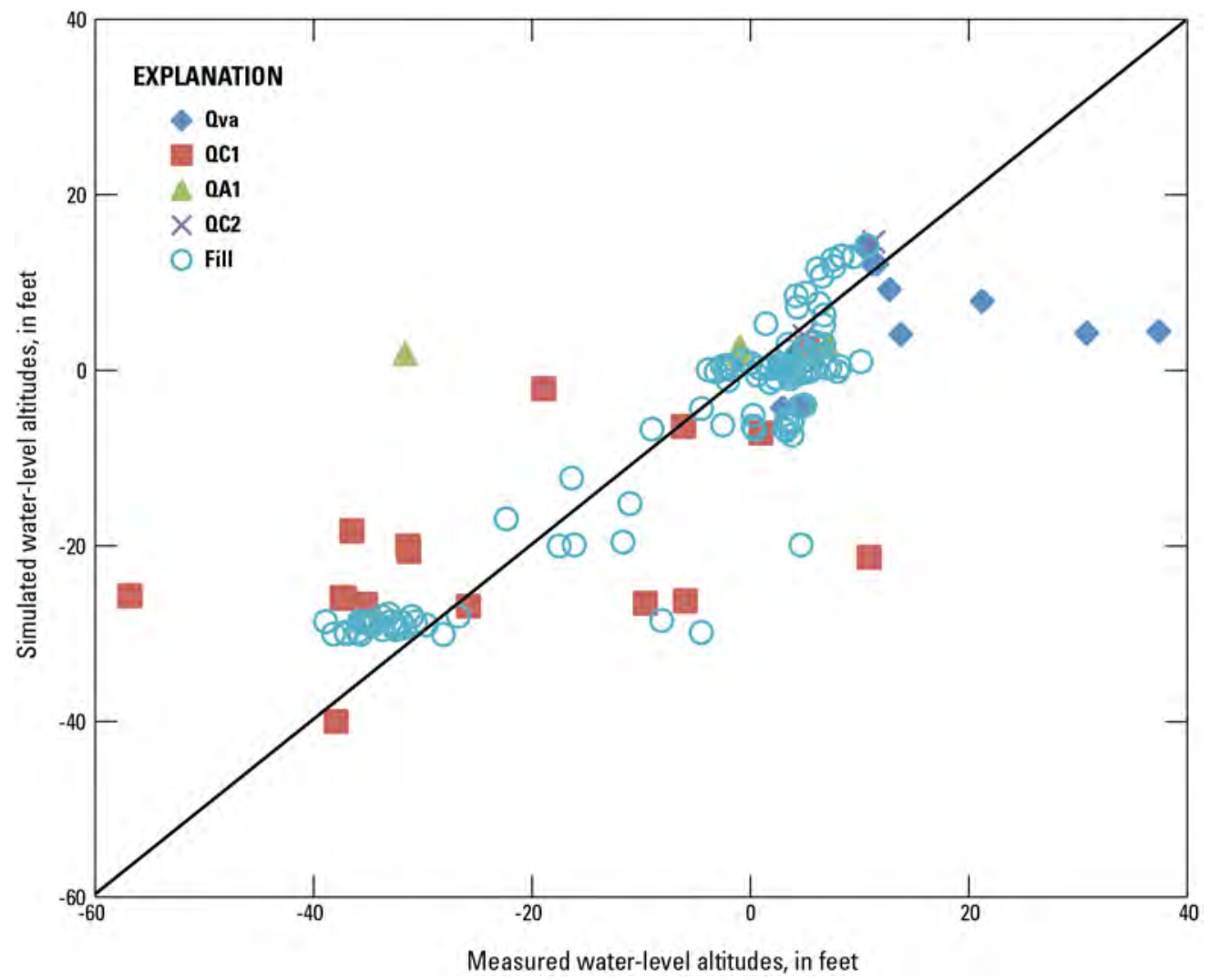

Figure 5. Graph showing simulated and measured water-level altitudes for the groundwater flow model, Puget Sound Naval Shipyard, Naval Base Kitsap, Bremerton, Washington 


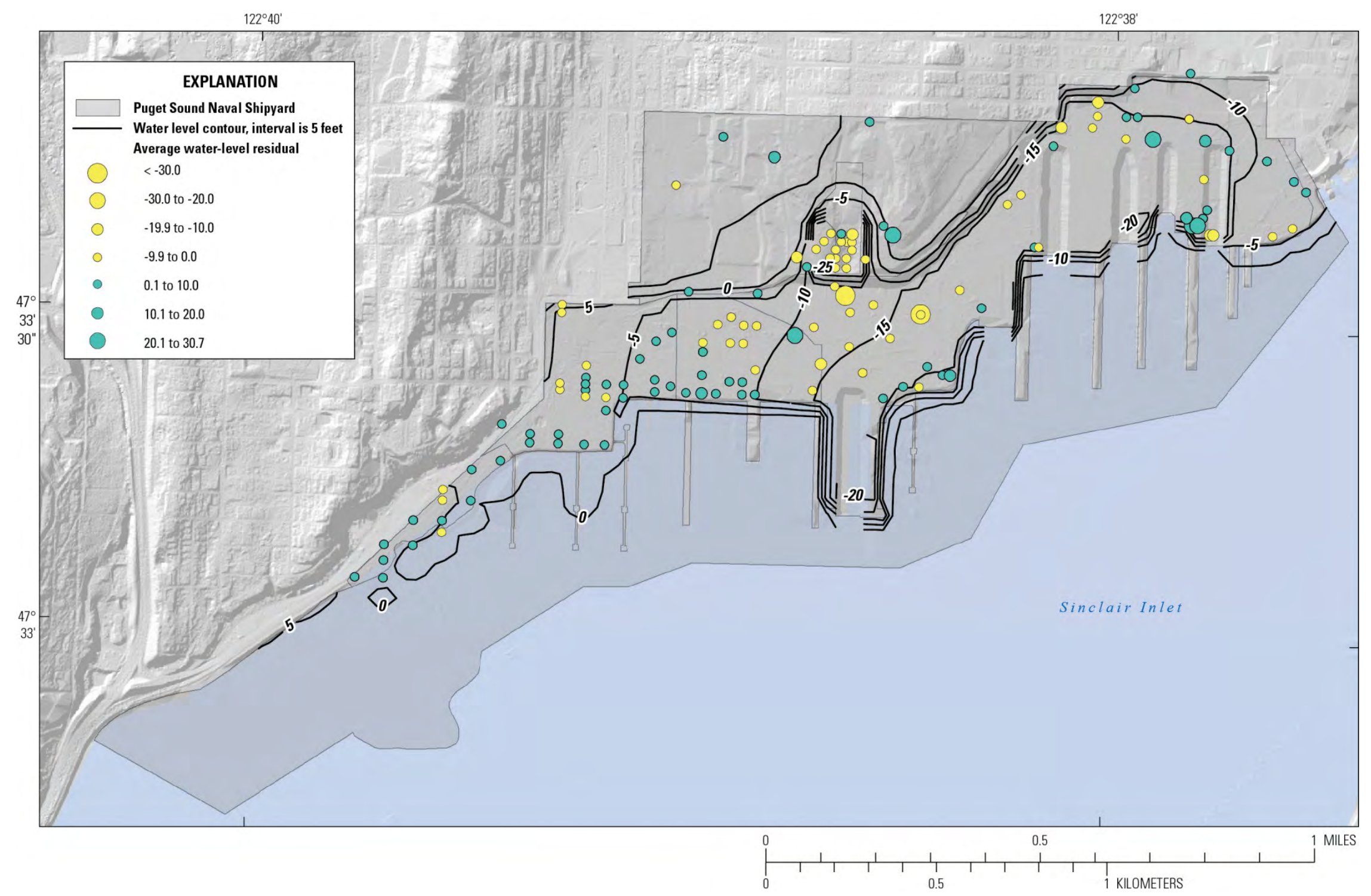

Figure 6. Map showing water-level residuals and water-level contours for layer 6 for the groundwater flow model, Puget Sound Naval Shipyard, Naval Base Kitsap, Bremerton, Washington. 


\section{Model Limitations}

A groundwater-flow model is a simplification of a complex natural system with a set of mathematical equations that describe the groundwater-flow system. Intrinsic to the model is the error and uncertainty associated with the approximations, assumptions, and simplifications that must be made. Hydrologic-modeling errors typically are the consequence of a combination of (1) input data, (2) representation of the physical processes by the algorithms of the model, and (3) parameter estimation during the calibration procedure (Troutman, 1985). Examples of model errors and how those errors limit application of the model include:

1. Input data on types and thicknesses of hydrogeologic units, water levels, and hydraulic properties represent only approximations of actual values. Model-discretization errors (including effects of averaging altitude information over the model cell size) result from inaccuracies in the geometric representation of hydrogeologic units, in the representation of the aquifer areas and their contact with adjacent units, and from potentially unmapped discontinuities in layer extents or properties, as might result from localized geologic disturbances such as landslides, stream channels, or fault zones. The physical processes within a groundwater-flow system cannot be represented completely in a numerical model. Determining if a weakness in a simulation is attributable to input data error or model shortcomings is almost impossible, but the simplifying assumptions and generalizations that are incorporated into a model undoubtedly affect the results of the simulation. Deriving useful insight from added model complexity requires good constraint on the properties and processes being added, but in the absence of such knowledge a simplified model will provide a more generalized result.

2. Errors in parameter estimates occur when improper values are selected during the calibration process. Various combinations of parameter values can result in low residual error, yet improperly represent the actual system. An acceptable degree of agreement between simulated and measured values does not guarantee that the estimated model-parameter values uniquely and reasonably represent the actual parameter values. The use of nonlinear regression and associated statistics, such as composite scaled sensitivities and correlation coefficients, removes some of the effects of non-uniqueness, but does not eliminate the problem entirely. Aquifer properties will vary within a geologic unit in a way not captured by calibration schemes that assume uniform values for each hydrogeologic layer.

If the numerical simulation is used appropriately, the effects of the simplifications and other potential errors can be minimized. If the model is used for simulations beyond which it was designed, however, the generalizations and assumptions used could significantly affect the results. 


\section{Model Applications}

\section{Water Budget}

An approximate steady-state groundwater budget for the study area is expressed as:

$$
R_{p p t}+G W_{i n}=D
$$

where

$R_{p p t}$ is recharge from precipitation,

$G W_{i n}$ is groundwater or seawater flowing into the study area, and

$D$ is discharge.

Sources of groundwater in the study area include recharge from precipitation and groundwater inflow from the west. Discharge from the system occurs as seepage to seepage faces; drainage to the dry docks; and as submarine seepage to Puget Sound.

A more detailed representation of the groundwater budget of the study area is:

$$
R_{p p t}+G W_{i n}=D_{s w}+D_{P S}+D_{d d}
$$

where

$D_{s w} \quad$ is discharge to surface drains,

$D_{P S} \quad$ is discharge to Puget Sound, and

$D_{d d} \quad$ is discharge to the dry docks.

Total simulated flow through the groundwater system is $19.70 \mathrm{ft}^{3} / \mathrm{s}$ (table 2). Recharge accounts for $2.47 \mathrm{ft}^{3} / \mathrm{s}$ of inflow to the study area and groundwater inflow accounts for $17.23 \mathrm{ft}^{3} / \mathrm{s}$. Discharge from the entire model domain is primarily through discharge to Puget Sound, and secondarily to the dry docks. Discharge to Puget Sound accounts for $15.34 \mathrm{ft}^{3} / \mathrm{s}$ of outflow and discharge to the dry docks accounted for $4.36 \mathrm{ft}^{3} / \mathrm{s}$. The simulated discharge to the dry docks is less than the $8.65 \mathrm{ft}^{3} / \mathrm{s}$ of groundwater discharge measured by Prych (1995). However, simulated discharge is within the estimated accuracy of 30-50 percent for the measured discharge to dry docks.

Table 2. Water budget for steady-state groundwater conditions for the groundwater flow model, Puget Sound Naval Shipyard, Naval Base Kitsap, Bremerton, Washington.

[Data are in cubic feet per second]

\begin{tabular}{lc|lc}
\hline \multicolumn{1}{c|}{ Inflow } & Rate & \multicolumn{1}{c}{ Outflow } & Rate \\
\hline Recharge from precipitation $\left(R_{p p t}\right)$ & 2.47 & Discharge to surface drains $\left(D_{s w}\right)$ & $3.66 \times 10^{-3}$ \\
Groundwater inflow (GWin) & 17.23 & Discharge to Puget Sound $\left(D_{P S}\right)$ & 15.34 \\
& & Discharge to dry docks $\left(D_{d d}\right)$ & 4.36 \\
\cline { 2 - 3 } Total & 19.70 & & 19.70 \\
\hline
\end{tabular}




\section{Simulation of Particle Tracking}

MODPATH (Pollock, 1994) is a particle-tracking post-processing package that was developed to compute three-dimensional flow paths using output from groundwater-flow simulations by MODFLOW. In this study, MODPATH version 5.0 was used for both forward and backward tracking of particles. Particle tracking is useful because it can indicate the flow path of a conservative (nonreactive) solute ("particle") transported in groundwater given a starting location (forward tracking) such as the water table or a contaminated location. It can also indicate where a "particle" may have originated given a specific ending location (backward tracking). Thus, general flow patterns and discharge areas simulated by a groundwater model can be depicted, and capture areas may be estimated.

\section{MODPATH Procedure}

The computer model MODPATH uses a semi-analytical, particle-tracking scheme. The method is based on the assumption that each directional-velocity component (calculated from MODFLOW output) varies linearly within each model cell. This assumption allows an analytical expression describing the flow path within each cell to be obtained using the simulated flows through the faces of the cell. The velocity of groundwater is affected by the porosity of the material through which the groundwater is flowing. Specified porosities for layers in the updated model were 0.2 for the Qvt unit; 0.3 for the Fill, Qva, QA1, and QA2 units; and 0.4 for the QC1, QC2, QC3, and QC4 units, based on published values for similar geologic units (Fetter, 1994). Given the initial position of a particle, the position of the particle at any future time can be calculated. A series of calculations for successive locations of a particle provide a simulated particle path through the model domain. See Pollock (1994) for a detailed discussion of the particle-tracking procedure.

MODPATH can run either a forward simulation or a backward simulation. Both were run in this study. MODPATH requires the initial locations of the particles to be specified as to which cell, and how many particles are to be tracked from that cell. Particles may be placed on cell faces or edges. In a forward simulation, initial particle locations within or on the faces and (or) edges of model cells are specified and particle paths are calculated from those starting points to where the particles discharge from the model domain. In a backward simulation, particle ending locations (such as a monitoring well or dry-dock drain) are specified on the faces and(or) edges of the model cell in question, and a particle path is calculated from that ending point backward to where the particle entered the model domain.

In the forward simulation, particles were released at the start of the steady-state stress period at the water table in every fifth cell in every fifth row (one particle per 25 cells) within the shipyard boundary and tracked forward to their discharge points. The resulting particle paths provide a picture of the general flow directions and discharge locations for the whole model domain. A total of 601 particles were released for the forward simulation. 
The forward simulated groundwater flowpaths are similar to the forward tracking paths Prych (1997) simulated, and indicate that most of the groundwater recharge from precipitation within the shipyard boundary discharges to the dry docks (fig. 7). Most of the recharge from precipitation that recharges on the western end of the shipyard discharges to dry docks 5 and 6, with the exception of the far western end where the flowpaths terminate in Puget Sound. There is also a small wedge between dry docks 5 and 6 where the flowpaths terminate in Puget Sound. Many of the particles that originate in the northwestern corner of the shipyard flow preferentially through a small valley that was filled in to the north of the main artificial fill area north of dry dock 6 . The water-level altitudes in this filled valley are substantially lower than those in the surrounding native material on either side, leading the flowpaths through the filled valley before turning to the east and terminating in dry dock 5. Groundwater that recharges on the eastern end of the shipyard all discharges to dry docks 1, 3, and 4. Dry dock 4 draws water from either side as well as some from the far side of dry dock 2. Dry dock 2 was constructed without drains so no water is simulated to flow into it. The sheet-pile cutoff walls around dry docks 1 and 3 exert a large influence on nearby flow paths. Dry dock 3 has more extensive sheet-pile cutoff walls that dry dock 1, causing groundwater that recharges to the east to bypass dry dock 3 and discharge into dry dock 1.

For the backward simulation, particles were released at the end of the steady-state stress period at model cells containing each of 43 long-term monitoring wells, and MODPATH backtracked the particles to indicate where they entered the groundwater-flow system. Initial particle locations at each cell that contained one of the 43 long-term monitoring wells (fig. 8) were specified at the center of the cells and at the center of each of the 6 cell faces, for a total of 7 particles per cell. A total of 301 particles were released for the backward simulation. The backward particle tracking (fig. 8) indicates that the most of the flowpaths that terminate at the long-term monitoring wells originate to the northwest of the shipyard, and that only a few wells intercept groundwater that originates as recharge within the shipyard boundary. Groundwater that originates farther north beyond the flowpath lines shown in figure 8 would likely discharge to the east in Puget Sound. 


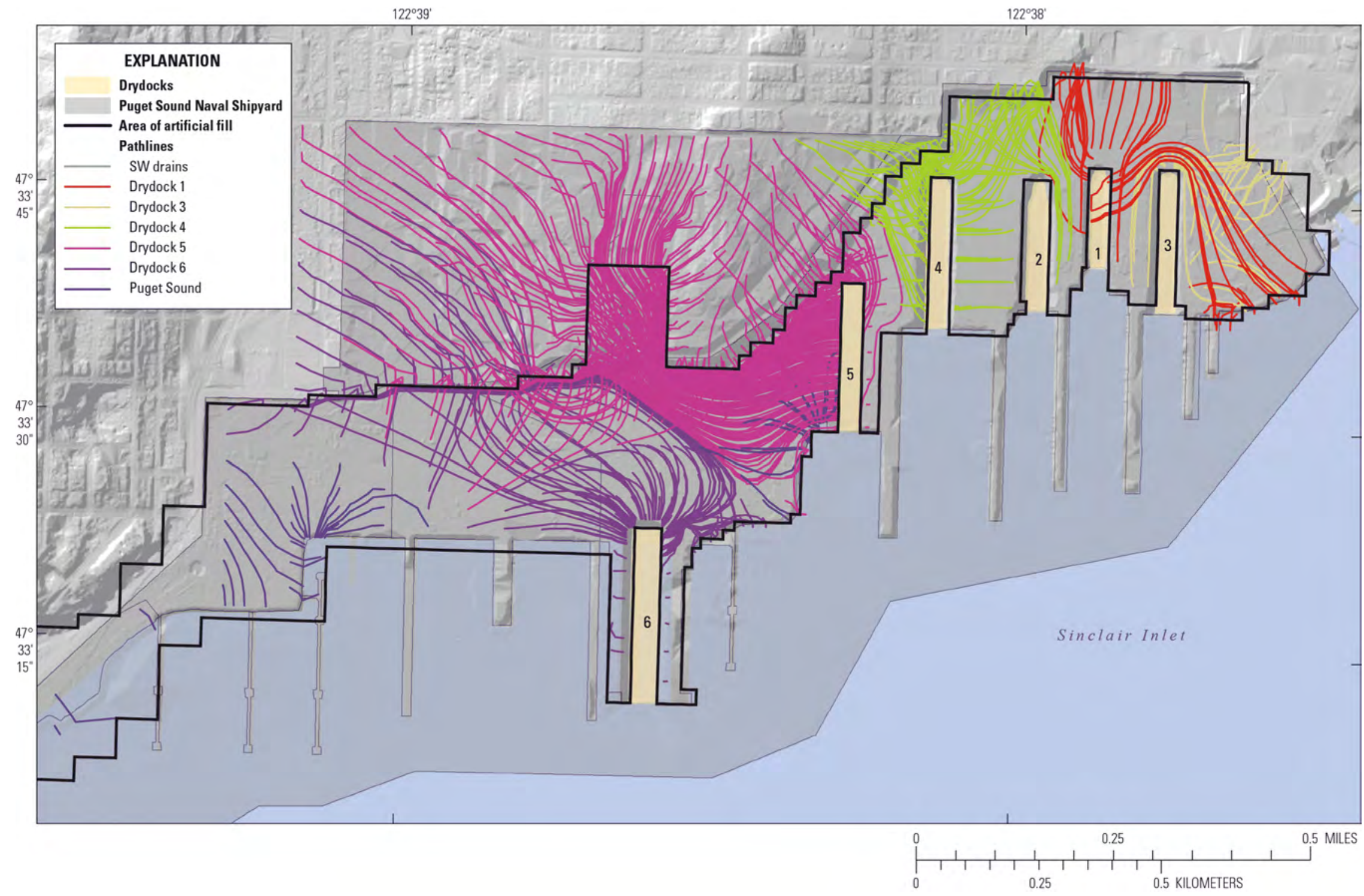

Figure 7. Map showing forward particle tracking from selected model cells within the shipyard for the groundwater flow model, Puget Sound Naval Shipyard, Naval Base Kitsap, Bremerton, Washington. 


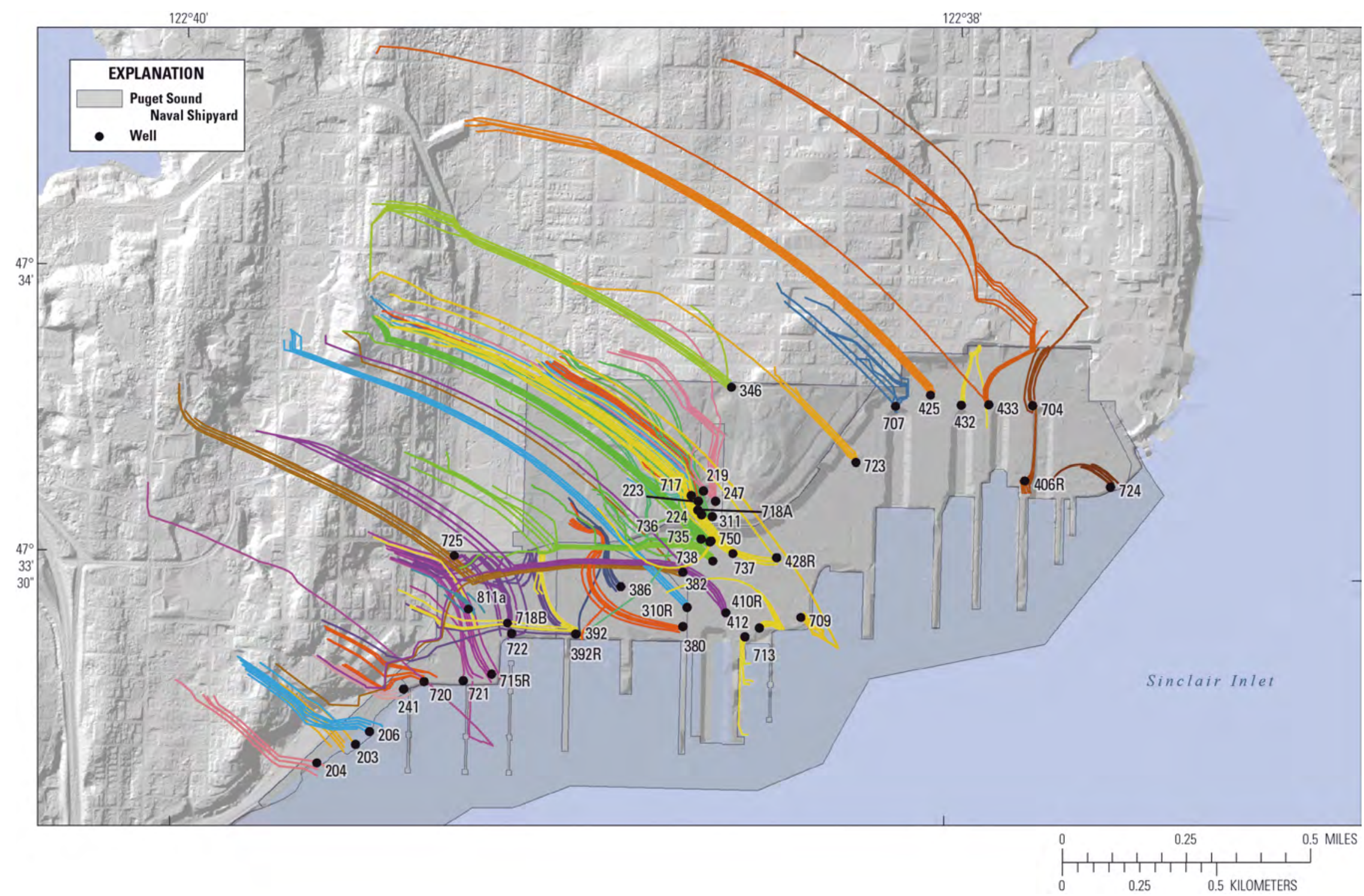

Figure 8. Map showing backward particle tracking from long-term monitoring wells for the groundwater flow model, Puget Sound Naval Shipyard, Naval Base Kitsap, Bremerton, Washington. 


\section{Summary}

Puget Sound Naval Shipyard is located on the northern shore of Sinclair Inlet in Puget Sound. A 1997 multi-layer steady-state groundwater-flow model with homogeneous hydraulic characteristics was updated with new interpretations of hydrogeologic unit presence and thickness, new recharge estimates (from precipitation as well as inflow from the regional groundwater system - using General Head boundaries to determine the amount of regional groundwater inflow), new calibrated hydraulic parameter values, and increased vertical and areal resolution.

The shipyard and surrounding area overlies glacial and interglacial deposits and a substantial amount of fill along the shoreline to support terrestrial activities. Present in the model area are Vashon Till (Qvt), Vashon advance outwash (Qva), and seven older and deeper layers of alternately confining units and aquifer units. In the updated groundwater flow model, these are represented by 22 model layers and are calibrated such that each layer may have unique hydraulic characteristics.

Annual precipitation of more than 56 inches results in recharge rates ranging between 0 and about 33 inches per year. Groundwater-flow directions reflect the regional pattern in the area-from topographic highs in the north and northwest generally south and southeast toward Puget Sound. Dry docks, with bottom altitudes ranging from -16.5 to $-45.5 \mathrm{ft}$, are significant discharge locations.

The updated steady-state numerical (finite difference) groundwater model comprises 22 layers, 104 rows, and 141 columns, with thinner layers at the top and narrower rows and columns at the locations of the dry docks. General head boundaries were used at the model perimeter except where horizontal flow barriers are used to represent bulkheads. The dry docks are represented by drain boundary cells. The bottom of the model is specified as a no-flow boundary.

The updated model was calibrated using parameter estimation to average 2001-2005 water levels at monitoring wells within the shipyard. The final calibration had a mean residual value of +1.15 $\mathrm{ft}$. The flow directions and discharge locations predicted by this updated model generally match the 1997 model despite refinements and other changes.

Particle tracking using MODPATH was conducted in forward and backward tracking modes. For forward tracking, particles were assigned starting points at the water table for 4 percent ( 1 for every 25 cells) of the active model cells within the shipyard and tracked to their final discharge locations. This allowed pathlines to be associated with specific drain boundary cells. For backward tracking, 7 particles per cell (center of all cells faces plus one centroid) were placed in 43 cells representing the screened intervals of long-term monitoring wells, and allowed to track backwards to the water table. This allowed each monitoring well to be associated with a recharge zone, and is intended to aid in evaluating the usefulness of the monitoring network with regard to specific source areas.

In the updated model, most groundwater discharge recharged within the boundaries of the shipyard is to the dry docks; only at the western end of the shipyard does groundwater discharge directly to Puget Sound. Backward particle tracking for the existing long-term monitoring well network suggests that only a few wells intercept groundwater that originates as recharge within the shipyard boundary. 


\section{References Cited}

Anderson, M.R., and Woessner, W.W., 1992, Applied groundwater modeling simulation of flow and advective transport: San Diego/New York/Boston/London/Sydney/ Tokyo/Toronto, Academic Press, Inc., $381 \mathrm{p}$.

Bidlake, W.R., and Payne, K.L., 2001, Estimating recharge to groundwater from precipitation at Naval Submarine Base Bangor and vicinity, Kitsap County, Washington: U.S. Geological Survey WaterResources Investigations Report 01-4110,33 p. [Also available at https://pubs.er.usgs.gov/publication/wri014110.]

Doherty, J., 2005, PEST-Model-independent parameter estimation: Corinda, Australia, Watermark Numerical Computing, [variously paged].

Doherty, J., 2006, Addendum to PEST manual: Corinda, Australia, Watermark Numerical Computing, [variously paged].

Drost, B.W., Ely, D.M., and Lum, W.E., 1999, Conceptual model and numerical simulation of the ground-water flow system in the unconsolidated sediments of Thurston County, Washington: U.S. Geological Survey Water-Resources Investigations Report 99-4165, 106 p. [Also available at http://pubs.usgs.gov/wri/wri994165/.]

Fetter, C.W., 1994, Applied hydrogeology, 3rd ed.: Prentice Hall, 691 p.

Frans, L.M., and Olsen, T.D., 2016, Numerical simulation of the groundwater-flow system of the Kitsap Peninsula, west-central Washington: U.S. Geological Survey Scientific Investigations Report 20165052, 63 p., http://dx.doi.org/10.3133/sir20165052.

Hill, M.C., and Tiedeman, C.R., 2007, Effective groundwater model calibration — with analysis of data, sensitivities, predictions and uncertainty: Hoboken, N.J., Wiley, 464 p.

Hsieh, P.A., and Freckleton, J.R., 1993, Documentation of a computer program to simulated horizontalflow barriers using the U.S. Geological Survey's modular three-dimensional finite-difference groundwater flow model: U.S. Geological Survey Open-File Report 92-447, 32 p.

Jones, M.A., 1996, Thickness of unconsolidated deposits of the Puget Sound aquifer system, Washington and British Columbia: U.S. Geological Survey Water-Resources Investigations Report 94-4133, 1 pl., scale 1:500,000.

Kipp, K.L., 1987, HST3D A computer code for simulation of heat and solute transport in threedimensional ground-water flow systems: U.S. Geological Survey Water-Resources Investigations Report 86-4095, 517 p.

National Oceanic and Atmospheric Administration - National Climate Data Center, 2014: accessed April 2014, http://www1.ncdc.noaa.gov/pub/data/normals/1981-2010.

Niswonger, R.G., Panday, Sorab, and Ibaraki, Motomu, 2011, MODFLOW-NWT, A Newton formulation for MODFLOW-2005: U.S. Geological Survey Techniques and Methods, book 6, chap. A37, 44 p.

Pollock, D.W., 1994, User's guide for MODPATH/ MODPATH-PLOT, Version 3-A particle tracking post-processing package for MODFLOW, the U.S. Geological Survey finite-difference ground-water flow model: U.S. Geological Survey Open-File Report 94-464, variously paginated.

Prych, E.A., 1995, Data on quantity and quality of water flowing in drainage systems of dry docks at Puget Sound Naval Shipyard, Bremerton, Washington, 1994: U.S. Geological Survey Open-File Report 95-361, 58 p.

Prych, E.A., 1997, Numerical simulation of ground-water flow paths and discharge locations at Puget Sound Naval Shipyard, Bremerton, Washington: U.S. Geological Survey Water-Resources Investigations Report 96-4147, 43 p. 
Puget Sound LiDAR Consortium, 2000, PSLC2000—Bare Earth LiDAR DE $<$ : Puget Sound LiDAR Consortium Web site, accessed September 20, 2007, at http://pugetsoundlidar.ess.washington.edu. Sealaska Environmental Services, LLC, 2015, Long-term monitoring trend analysis: Report for OUA OU NSC, OUB T PMP, OU C, and OU D: Summer/Fall 2013 through Summer 2014.

Sealaska Environmental Services, LLC, 2016, Long-term monitoring trend analysis: Report for OUA OU NSC, OUB T PMP, OU C, and OU D: Summer/Fall 2014 through Summer 2015.

Troutman, B.M., 1985, Errors and parameter estimation in precipitation-runoff modeling 2-Case study: Water Resources Research, v. 21, no. 8, p. 1,214-1,222.

URS Consultants, Inc., 1992a, Site inspection report, Puget Sound Naval Shipyard, Bremerton, Washington, Site Inspection Report, vol. 1, 2, and 3 Naval Facilities Engineering Command, U.S. Navy CLEAN Program: Seattle, Wash, URS Consultants, Inc., CTO-0017, variously paged.

URS Consultants, Inc., 1992b, Hydrogeological and biological investigation, Puget Sound Naval Shipyard, Bremerton, Washington, Hydrogeological report Naval Facilities Engineering Command, U.S. Navy CLEAN Program: Seattle, Wash., URS Consultants, Inc., CTO-0036, variously paged.

URS Consultants, Inc., 1993a, Remedial investigation/feasibility study, Operable Unit NSC, Fleet and Industrial Supply Center, Bremerton, Washington, Draft Phase I Technical Memorandum: Naval Facilities Engineering Command, U.S. Navy CLEAN Program: Seattle, Wash., URS Consultants, Inc., CTO 0087, variously paged.

URS Consultants, Inc., 1993b, Remedial investigation/feasibility study, Operable Unit NSC, Fleet and Industrial Supply Center, Bremerton, Washington, Appendices A-G, Draft Phase I Technical Memorandum: Naval Facilities Engineering Command, U.S. Navy CLEAN Program: Seattle, Wash., URS Consultants, Inc., CTO-0087, variously paged.

URS Consultants, Inc., 1993c, Remedial investigation/feasibility study, Operable Unit A, Puget Sound Naval Shipyard, Bremerton, Washington, Draft Phase I Technical Memorandum: Naval Facilities Engineering Command, U.S. Navy CLEAN Program: Seattle, Wash., URS Consultants, Inc., CTO0094, variously paged.

URS Consultants, Inc., 1993d, Remedial investigation/feasibility study, Operable Unit A, Puget Sound Naval Shipyard, Bremerton, Washington, Appendixes A-H, Draft Phase I Technical Memorandum: Naval Facilities Engineering Command, U.S. Navy CLEAN Program: Seattle, Wash., URS Consultants, Inc.

URS Consultants, Inc., 1994a, Remedial investigation/feasibility study, Operable Unit B, Puget Sound Naval Shipyard, Bremerton, Washington, Phase I Technical Memorandum vol. 1, 2 and 3, Naval Facilities Engineering Command, U.S. Navy CLEAN Program: Seattle, Wash., URS Consultants, Inc., CTO 0131, variously paged.

URS Consultants, Inc., 1994b, Final Work Plan for the Remedial Investigation/Feasibility Study, Operable Unit B, Puget Sound Naval Shipyard, Bremerton Naval Complex, Bremerton, Washington. URS Consultants, Inc. Seattle, Washington.

URS Consultants, Inc., 2002, Final Remedial Investigation Report, Operable Unit B, Bremerton Naval Complex, Bremerton, Washington. Prepared for Engineering Field Activity, Northwest by URS Consultants under CLEAN Contract No. N62474-89-D-9295, CTO 0131. March 2002.

U.S. Navy, 1983, Initial Assessment Study of Naval Shipyard Puget Sound, Bremerton, Washington: NEESA 13-022, Naval Energy and Environmental Support Activity, Port Hueneme, California. March 1983.

U.S. Navy, 1990, Preliminary assessment supplemental report, Puget Sound Naval Shipyard, Bremerton, Washington: NEESA 13-022A, Ordnance Environmental Support Office, Indian Head, Maryland, June 1990. 
U.S. Navy, 1995a, Final remedial investigation report, Operable Unit NSC, Bremerton Naval Complex, Bremerton, Washington: Prepared for EFA NW by URS Consultants, Inc. under CLEAN Contract No. N62474-89-D-9295. September 1995.

U.S. Navy, 1995b, Final remedial investigation report, Operable Unit A, Bremerton Naval Complex, Bremerton, Washington: Prepared for EFA NW by URS Consultants, Inc. under CLEAN Contract No. N62474-89-D-9295, August 1995.

U.S. Navy, 1995c, Final feasibility study, Operable Unit A, Bremerton Naval Complex, Bremerton, Washington: Prepared for EFA NW by URS Consultants, Inc. under CLEAN Contract No. N6247489-D-9295, October 1995.

U.S. Navy, 1996, Draft remedial investigation report, Operable Unit B, Puget Sound Naval Shipyard, Bremerton, Washington: Prepared for Engineering Field Activity, Northwest by URS Consultants, Inc. under CLEAN Contract No. N62474-89-D-9295, September 1996.

U.S. Navy, 2002a, Appendix BB of Phase I Groundwater Modeling: Flow Simulation Near Drydock 4, Final RI Report, Bremerton Naval Complex OU B, Contract No. N62474-89-D-9295.

U.S. Navy, 2004, Final remedial investigation/feasibility study report, Operable Unit D, Bremerton Naval Complex, Bremerton, Washington: Prepared for Engineering Field Activity, Northwest, by URS Group, Inc., under Contract No. N44255-02-D-2008, March 2004.

U.S. Navy, Washington State Department of Ecology, and U.S. Environmental Protection Agency (U.S. Navy, Ecology, and USEPA), 1997, Final Record of Decision, Operable Unit A, Missouri Beach Parking Lot and Charleston Beach, Bremerton Naval Complex, Bremerton, Washington, Executed January 29, 1997.

van Heeswijk, Marijke, and Smith, D.T., 2002, Simulation of the ground-water flow system at Naval Submarine Base Bangor and vicinity, Kitsap County, Washington: U.S. Geological Survey WaterResources Investigations Report 02-4261, 142 p.

Washington State Department of Ecology, 2007, Letter from Ben Amoah-Forson (Ecology) to Suzanna M. Jefferis (Navy) re: Letter of Approval for the Final Cleanup Action Plan (CAP), Operable Unit C, Bremerton Naval Complex, Bremerton, Washington, September 2006, December 17, 2007.

Welch, W.B., Frans, L.M., and Olsen, T.D., 2014, Hydrogeologic framework, groundwater movement, and water budget of the Kitsap Peninsula, west-central Washington: U.S. Geological Survey Scientific Investigations Report 2014-5106, 44 p. 
Table 3. Wells, measured water level altitudes, and model cell assignments used in calibration.

[IRIMS is Installation Restoration Information Management System; water-level altitude in feet above NAVD88; see section "Hydrogeologic Units" for descriptions; FILL is artificial fill]

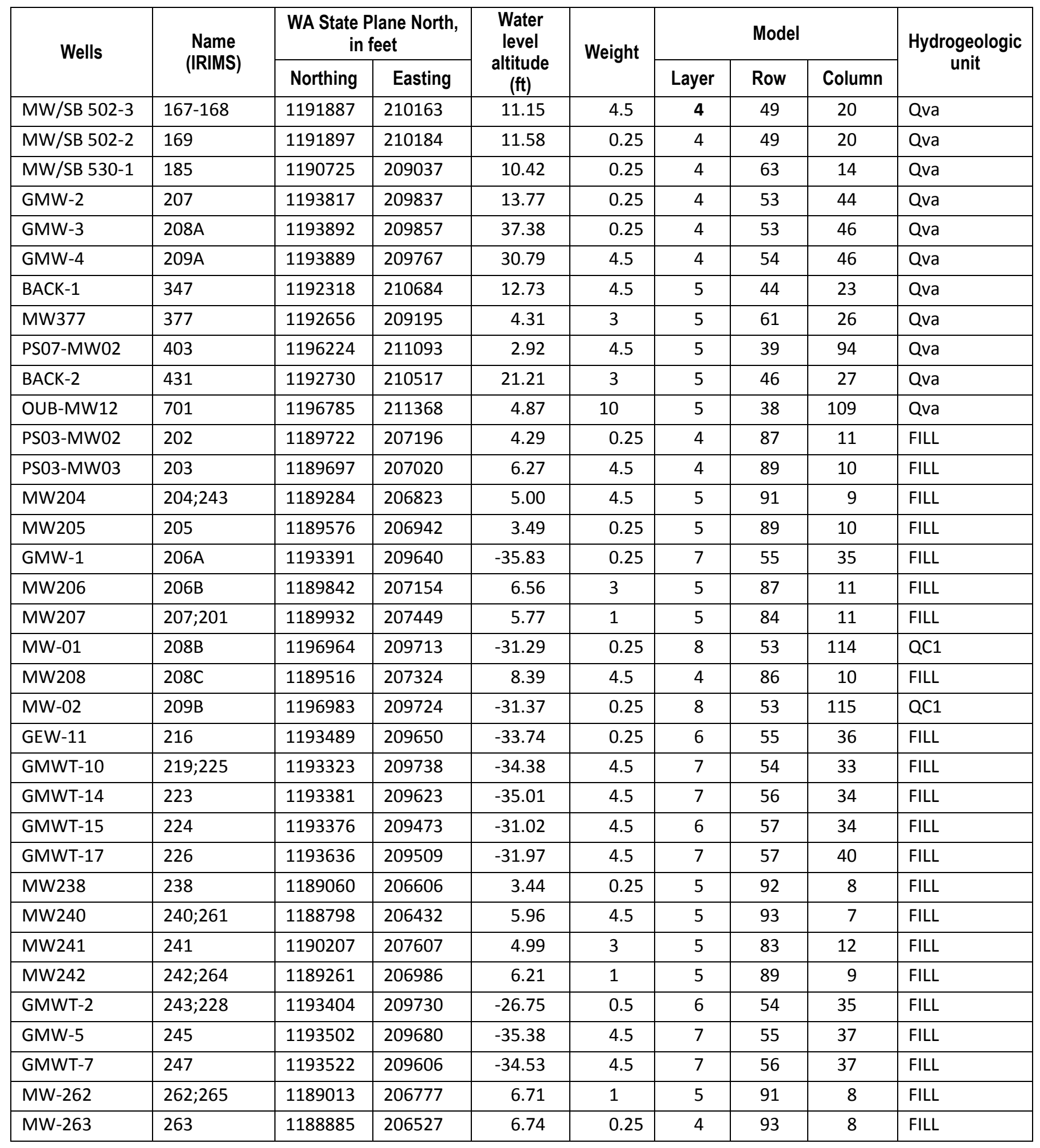




\begin{tabular}{|c|c|c|c|c|c|c|c|c|c|}
\hline \multirow{2}{*}{ Wells } & \multirow{2}{*}{$\begin{array}{l}\text { Name } \\
\text { (IRIMS) }\end{array}$} & \multicolumn{2}{|c|}{$\begin{array}{l}\text { WA State Plane North, } \\
\text { in feet }\end{array}$} & \multirow{2}{*}{$\begin{array}{c}\text { Water } \\
\text { level } \\
\text { altitude } \\
\text { (ft) }\end{array}$} & \multirow{2}{*}{ Weight } & \multicolumn{3}{|c|}{ Model } & \multirow{2}{*}{$\begin{array}{c}\text { Hydrogeologic } \\
\text { unit }\end{array}$} \\
\hline & & Northing & Easting & & & Layer & Row & Column & \\
\hline MW-266 & 266 & 1189576 & 207221 & 6.15 & 10 & 4 & 87 & 10 & FILL \\
\hline MW-267 & 267 & 1190135 & \begin{tabular}{|l|}
207887 \\
\end{tabular} & 10.10 & 0.25 & 5 & 79 & 12 & FILL \\
\hline PS12-MW01 & 301 & 1192138 & 208733 & -2.57 & 3 & 5 & 67 & 22 & FILL \\
\hline PS12-MW02 & 302 & 1192120 & 208605 & 0.79 & 3 & 5 & 68 & 22 & FILL \\
\hline PS12-MW03 & 303 & 1192113 & 208412 & 3.08 & 4.5 & 5 & 71 & 22 & FILL \\
\hline PS10W-MW04 & 304 & 1192545 & 208446 & -2.06 & 4.5 & 5 & 70 & 26 & FILL \\
\hline PS02-MW01 & 305 & 1191600 & 208316 & 1.53 & 4.5 & 5 & 72 & 19 & FILL \\
\hline PS02-MW04W & 307 & 1191576 & 208758 & 2.69 & 3 & 5 & 67 & 19 & FILL \\
\hline PS02-MW03 & 308 & 1191714 & \begin{tabular}{|l|}
208839 \\
\end{tabular} & 3.05 & 1 & 5 & 66 & 20 & FILL \\
\hline PS02-MW05 & $309 ; 901$ & 1191642 & 208212 & 1.87 & 1 & 5 & 74 & 19 & FILL \\
\hline MW310 & 310 & 1193221 & 208479 & -29.69 & 1 & 7 & 69 & 32 & FILL \\
\hline MW-310R & $310 R$ & 1193221 & 208473 & -37.39 & 1 & 8 & 69 & 32 & QC1 \\
\hline GMWT-9 & 311 & 1193489 & \begin{tabular}{|l|}
209442 \\
\end{tabular} & -35.28 & 1 & 7 & 58 & 36 & FILL \\
\hline MW312SHALO & $312 ; 385$ & 1192579 & \begin{tabular}{|l|}
208211 \\
\end{tabular} & 1.80 & 3 & 5 & 74 & 26 & FILL \\
\hline MW313 & 313 & 1191982 & 208219 & 3.29 & 4.5 & 5 & 74 & 21 & FILL \\
\hline MW316SHLLW & 316 & 1192300 & 208963 & -0.72 & 3 & 5 & 64 & 24 & FILL \\
\hline MW317 & 317 & 1193017 & 208733 & -8.13 & 0.5 & 7 & 66 & 29 & FILL \\
\hline MW318 & 318 & 1192597 & 208829 & -1.69 & 10 & 5 & 65 & 26 & FILL \\
\hline GMW-26 & 326 & 1193352 & \begin{tabular}{|l|}
209404 \\
\end{tabular} & -34.33 & 3 & 7 & 58 & 34 & FILL \\
\hline GMW-27 & 327 & 1193009 & 209539 & -18.93 & 3 & 6 & 57 & 29 & QC1 \\
\hline GMW-28 & 328 & 1193055 & 209390 & 0.95 & 4.5 & 6 & 58 & 30 & QC1 \\
\hline MW417DEEP & 350 & 1190740 & 209021 & 10.86 & 4.5 & 8 & 64 & 14 & QC1 \\
\hline MW312DEEP & 351 & 1192521 & \begin{tabular}{|l|}
208219 \\
\end{tabular} & -6.14 & 1 & 11 & 74 & 26 & QC1 \\
\hline MW378 & 378 & 1192523 & 208862 & -2.20 & 3 & 5 & 65 & 25 & FILL \\
\hline MW379 & 379 & 1192193 & 208880 & -0.03 & 4.5 & 5 & 65 & 23 & FILL \\
\hline MW380 & 380 & 1193175 & 208269 & -4.49 & 3 & 5 & 73 & 31 & FILL \\
\hline MW382 & 382 & 1193176 & 208850 & -34.98 & 1 & 7 & 65 & 31 & FILL \\
\hline MW383 & 383 & 1191840 & \begin{tabular}{|l|}
208294 \\
\end{tabular} & 2.59 & 0.25 & 5 & 73 & 20 & FILL \\
\hline MW386 & 386 & 1192516 & 208696 & -3.14 & 3 & 5 & 67 & 25 & FILL \\
\hline MW388 & 388 & 1192321 & \begin{tabular}{|l|}
208667 \\
\end{tabular} & -2.23 & 4.5 & 5 & 67 & 24 & FILL \\
\hline MW389 & 389 & 1192433 & 208187 & 3.63 & 3 & 5 & 74 & 25 & FILL \\
\hline MW390 & 390 & 1192316 & \begin{tabular}{|l|}
208337 \\
\end{tabular} & 0.61 & 1 & 5 & 72 & 24 & FILL \\
\hline MW391 & 391 & 1192521 & 208334 & 2.32 & 3 & 5 & 72 & 25 & FILL \\
\hline MW392 & 392 & 1192047 & 208191 & 7.96 & 3 & 5 & 74 & 22 & FILL \\
\hline MW392R & $392 R$ & 1192035 & 208191 & 3.80 & 4.5 & 6 & 74 & 22 & FILL \\
\hline PS01-MW01 & 400 & 1194423 & 208366 & 6.70 & 3 & 4 & 70 & 53 & FILL \\
\hline PS01-MW02 & 401 & 1194196 & 208274 & 1.42 & 3 & 4 & 72 & 50 & FILL \\
\hline PS07-MW01 & 402 & 1196261 & 210843 & -11.04 & 4.5 & 6 & 41 & 95 & FILL \\
\hline PS08-MW01A & $404 ; 752 ; 756$ & 1196912 & 209908 & -16.14 & 1 & 6 & 51 & 112 & FILL \\
\hline
\end{tabular}




\begin{tabular}{|c|c|c|c|c|c|c|c|c|c|}
\hline \multirow{2}{*}{ Wells } & \multirow{2}{*}{$\begin{array}{l}\text { Name } \\
\text { (IRIMS) }\end{array}$} & \multicolumn{2}{|c|}{$\begin{array}{l}\text { WA State Plane North, } \\
\text { in feet }\end{array}$} & \multirow{2}{*}{$\begin{array}{c}\text { Water } \\
\text { level } \\
\text { altitude } \\
\text { (ft) }\end{array}$} & \multirow{2}{*}{ Weight } & \multicolumn{3}{|c|}{ Model } & \multirow{2}{*}{$\begin{array}{c}\text { Hydrogeologic } \\
\text { unit }\end{array}$} \\
\hline & & Northing & Easting & & & Layer & Row & Column & \\
\hline PS08-MW01B & 405 & 1196912 & 209914 & -25.83 & 0.5 & 8 & 51 & 112 & QC1 \\
\hline PS08-MW02A & 406 & 1196818 & 209824 & 0.39 & 1 & 5 & 52 & 110 & FILL \\
\hline PS08MW02A- & $406 \mathrm{R}$ & 1196823 & 209829 & 4.63 & 3 & 6 & 52 & 111 & FILL \\
\hline PS08-MW02B & 407 & 1196777 & 209830 & -5.97 & 1 & 8 & 52 & 110 & QC1 \\
\hline PS08-MW03A & 408 & 1196733 & 209884 & 3.11 & 3 & 5 & 51 & 109 & FILL \\
\hline PS08-MW03B & 409 & 1196732 & 209875 & -9.63 & 1 & 8 & 51 & 109 & QC1 \\
\hline PS09-MW01B & 410 & 1193634 & 208425 & -33.66 & 3 & 7 & 70 & 40 & FILL \\
\hline PS09- & $410 R$ & 1193639 & 208430 & -32.50 & 0.5 & 7 & 70 & 40 & FILL \\
\hline PS10E-MW01 & 411 & 1197550 & 209732 & 5.07 & 1 & 4 & 53 & 127 & FILL \\
\hline PS10C-MW01 & 412 & 1193993 & 208256 & 0.24 & 10 & 5 & 72 & 48 & FILL \\
\hline PS10C-MW02 & 413 & 1194762 & 209000 & -11.68 & 4.5 & 6 & 62 & 59 & FILL \\
\hline PS10C-MW03 & 414 & 1195263 & 209650 & -28.14 & 0.5 & 7 & 55 & 71 & FILL \\
\hline PS10C-MW04 & 415 & 1195326 & 209655 & -35.70 & 4.5 & 7 & 54 & 72 & FILL \\
\hline PS10W-MW01 & 416 & 1190318 & 207860 & 5.33 & 3 & 5 & 80 & 13 & FILL \\
\hline PS10W-MW02 & $417 ; 725$ & 1190719 & 209020 & 10.66 & 4.5 & 4 & 64 & 14 & FILL \\
\hline PS10W-MW03 & 418 & 1191083 & 208021 & 5.41 & 3 & 5 & 77 & 16 & FILL \\
\hline RPW-1B & 419 & 1190562 & 207831 & 3.48 & 3 & 5 & 80 & 14 & FILL \\
\hline RPW-2 & $420-1$ & 1190618 & 207754 & 3.95 & 4.5 & 5 & 81 & 14 & FILL \\
\hline OUB-MW01 & 422 & 1197514 & 210420 & 4.52 & 3 & 5 & 45 & 126 & FILL \\
\hline OUB-MW02 & 423 & 1196763 & 210879 & 3.84 & 10 & 5 & 41 & 109 & FILL \\
\hline OUB-MW04 & 425 & 1195810 & 210732 & -35.27 & 4.5 & 8 & 42 & 84 & QC1 \\
\hline OUB-MW05 & 426 & 1195138 & 210110 & -36.99 & 10 & 7 & 49 & 68 & FILL \\
\hline OUB-MW06 & 427 & 1194576 & 209227 & -35.96 & 4.5 & 7 & 60 & 55 & FILL \\
\hline OUB-MW07 & $428 \mathrm{R}$ & 1194171 & 209006 & -32.19 & 0.5 & 7 & 63 & 50 & FILL \\
\hline OUB-MW09 & 430 & 1193484 & 208666 & -32.66 & 4.5 & 7 & 67 & 37 & FILL \\
\hline PS07-MW03 & 432 & 1196141 & 210621 & -22.36 & 4.5 & 6 & 43 & 92 & FILL \\
\hline PS07-MW04 & 433 & 1196429 & 210629 & -4.51 & 4.5 & 7 & 43 & 99 & FILL \\
\hline PS11-MW03C & 670 & 1193516 & 209767 & -38.91 & 4.5 & 7 & 54 & 37 & FILL \\
\hline PS11-MW05 & 672 & 1193445 & 209474 & -30.69 & 0.5 & 7 & 57 & 36 & FILL \\
\hline OUB-MW13 & 702 & 1197903 & 210163 & 4.82 & 3 & 5 & 48 & 130 & FILL \\
\hline OUB-MW14 & 703 & 1197165 & 210576 & 0.25 & 10 & 5 & 44 & 119 & FILL \\
\hline OUB-MW15 & 704 & 1196900 & 210619 & 3.24 & 4.5 & 5 & 43 & 112 & FILL \\
\hline OUB-MW17 & 706 & 1195895 & 210920 & -37.07 & 3 & 7 & 41 & 85 & FILL \\
\hline OUB MW18 & 707 & 1195442 & 210612 & -37.95 & 4.5 & 8 & 44 & 75 & QC1 \\
\hline OUB-MW23 & 709 & 1194430 & 208370 & 3.81 & 3 & 5 & 70 & 54 & FILL \\
\hline OUB-MW19 & 710 & 1194238 & 208484 & -2.54 & 10 & 5 & 69 & 51 & FILL \\
\hline OUB-MW-20 & 713 & 1193837 & 208161 & 3.40 & 3 & 5 & 74 & 45 & FILL \\
\hline OUB-MW21 & 714 & 1193869 & 208763 & -31.62 & 1 & 7 & 66 & 46 & FILL \\
\hline OUB-MW24 & $715 R$ & 1191146 & 207759 & 3.53 & 3 & 5 & 81 & 16 & FILL \\
\hline
\end{tabular}




\begin{tabular}{|c|c|c|c|c|c|c|c|c|c|}
\hline \multirow{2}{*}{ Wells } & \multirow{2}{*}{$\begin{array}{l}\text { Name } \\
\text { (IRIMS) }\end{array}$} & \multicolumn{2}{|c|}{$\begin{array}{l}\text { WA State Plane North, } \\
\text { in feet }\end{array}$} & \multirow{2}{*}{$\begin{array}{c}\text { Water } \\
\text { level } \\
\text { altitude } \\
\text { (ft) }\end{array}$} & \multirow{2}{*}{ Weight } & \multicolumn{3}{|c|}{ Model } & \multirow{2}{*}{$\begin{array}{c}\text { Hydrogeologic } \\
\text { unit }\end{array}$} \\
\hline & & Northing & Easting & & & Layer & Row & Column & \\
\hline OUB-MW22 & $716 \mathrm{~A}$ & 1196917 & 210286 & -9.02 & 3 & 5 & 47 & 112 & FILL \\
\hline GMWT-20 & $716 B$ & 1193214 & 209614 & -33.12 & 4.5 & 6 & 56 & 31 & FILL \\
\hline GMWT-19 & 717 & 1193262 & 209669 & -32.92 & 3 & 7 & 55 & 32 & FILL \\
\hline GMWT-18 & $718 \mathrm{~A}$ & 1193336 & 209509 & -35.69 & 3 & 7 & 57 & 33 & FILL \\
\hline OUB-MW-25 & $718 \mathrm{~B}$ & 1191312 & 208310 & 5.22 & 4.5 & 5 & 73 & 17 & FILL \\
\hline LTMP-1 & 720_w & 1190425 & 207686 & 4.07 & 3 & 5 & 82 & 13 & FILL \\
\hline LTMP-2 & 721 & 1190840 & 207693 & 4.59 & 4.5 & 5 & 81 & 15 & FILL \\
\hline LTMP-3 & 722 & 1191357 & 208197 & 3.22 & 3 & 5 & 75 & 17 & FILL \\
\hline LTMP-4 & 723 & 1195016 & 210016 & -38.18 & 3 & 7 & 50 & 65 & FILL \\
\hline LTMP-5 & 724_w & 1197729 & 209759 & 4.18 & 3 & 4 & 52 & 129 & FILL \\
\hline GMWT-22 & 735 & 1193370 & 209203 & -16.38 & 3 & 6 & 60 & 34 & FILL \\
\hline GMWT-23 & 736 & 1193474 & 209180 & -34.44 & 3 & 7 & 61 & 36 & FILL \\
\hline GMWT-24 & 737 & 1193707 & 209050 & -34.61 & 3 & 7 & 62 & 42 & FILL \\
\hline GMWT-25 & 738 & 1193478 & 208965 & -34.92 & 3 & 7 & 63 & 37 & FILL \\
\hline GMWT-26 & 750 & 1193464 & 209173 & -56.82 & 4.5 & 8 & 61 & 36 & QC1 \\
\hline PS08-MW07 & 753 & 1196917 & 209986 & -17.52 & 1 & 6 & 50 & 113 & FILL \\
\hline MONITOR & $801-2$ & 1190726 & 208324 & 8.30 & 3 & 4 & 73 & 14 & FILL \\
\hline MONITOR & 803 & 1190896 & 208335 & 7.63 & 0.25 & 4 & 73 & 15 & FILL \\
\hline MONITOR & 804 & 1190734 & 208239 & 7.51 & 0.25 & 4 & 74 & 14 & FILL \\
\hline MONITOR & 805 & 1190865 & 208233 & 7.25 & 0.25 & 5 & 74 & 15 & FILL \\
\hline MONITOR & 806 & 1190935 & 208211 & 6.54 & 0.25 & 4 & 75 & 15 & FILL \\
\hline MONITOR & 807 & 1191068 & 208317 & 5.82 & 0.25 & 5 & 73 & 16 & FILL \\
\hline MONITOR & 808 & 1191173 & 208169 & -3.86 & 0.25 & 5 & 75 & 16 & FILL \\
\hline MONITOR & 809 & 1190896 & 208346 & 8.19 & 4.5 & 5 & 72 & 15 & FILL \\
\hline MONITOR & 810 & 1191003 & 208277 & 6.89 & 3 & 5 & 73 & 15 & FILL \\
\hline MONITOR & 811 & 1190889 & 208460 & 9.44 & 3 & 4 & 70 & 15 & FILL \\
\hline MW900 & 900 & 1191525 & 208548 & 3.83 & 1 & 5 & 69 & 18 & FILL \\
\hline MW902 & 902 & 1191927 & 209154 & 5.21 & 3 & 5 & 61 & 21 & QC1 \\
\hline MW903 & 903 & 1197815 & 210203 & 4.96 & 4.5 & 5 & 47 & 129 & FILL \\
\hline MW904 & 904 & 1196152 & 210879 & 3.29 & 4.5 & 5 & 41 & 92 & FILL \\
\hline MW905 & 905 & 1195894 & 210990 & -37.20 & 4.5 & 8 & 40 & 85 & QC1 \\
\hline MW907 & 907 & 1195523 & 210740 & -36.51 & 10 & 8 & 42 & 77 & QC1 \\
\hline PS11-MW01L & 346 & 1193695 & 210817 & 7.06 & 3 & 13 & 42 & 40 & QA1 \\
\hline MW316DEEP & 352 & 1192305 & 208963 & -0.96 & 3 & 13 & 64 & 24 & QA1 \\
\hline OUB-MW03 & 424 & 1196761 & 210871 & -1.03 & 10 & 13 & 41 & 109 & QA1 \\
\hline OUB-MW08 & 429 & 1194169 & 209000 & -31.65 & 3 & 14 & 63 & 50 & QA1 \\
\hline OUB-MW-16 & 705 & 1196264 & 210838 & 5.78 & 4.5 & 14 & 41 & 95 & QA1 \\
\hline MW-268 & 268 & 1189574 & 206936 & 11.27 & 0.25 & 16 & 90 & 10 & QC2 \\
\hline MW381 & 381 & 1192229 & 208227 & 4.90 & 1 & 15 & 74 & 23 & QC2 \\
\hline
\end{tabular}



Publishing support provided by the U.S. Geological Survey

Science Publishing Network, Tacoma Publishing Service Center

For more information concerning the research in this report, contact the Director, Washington Water Science Center

U.S. Geological Survey

934 Broadway, Suite 300

Tacoma, Washington 98402

http://wa.water.usgs.gov 
